NIST Technical Note 1474

\title{
Thermal Environment for Electronic Equipment Used by First Responders
}

M. K. Donnelly

W. D. Davis

J. R. Lawson

M. J. Selepak 


\title{
NIST Technical Note 1474
}

\section{Thermal Environment for Electronic Equipment Used by First Responders}

\author{
M. K. Donnelly \\ W. D. Davis \\ J. R. Lawson \\ M. J. Selepak \\ Building and Fire Research Laboratory
}

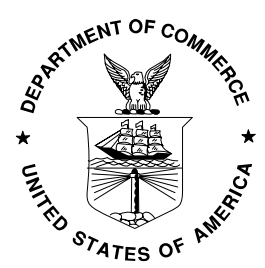

U.S. Department of Commerce Carlos M. Gutierrez, Secretary

Technology Administration William Jeffrey, Acting Under Secretary for Technology 
Certain commercial entities, equipment, or materials may be identified in this document in order to describe an experimental procedure or concept adequately. Such identification is not intended to imply recommendation or endorsement by the National Institute of Standards and Technology, nor is it intended to imply that the entities, materials, or equipment are necessarily the best available for the purpose.

National Institute of Standards and Technology Special Publication 1474

Natl. Inst. Stand. Technical Note 1457, 36 pages (January 2006)

CODEN: NSPUE2 


\section{Table of Contents}

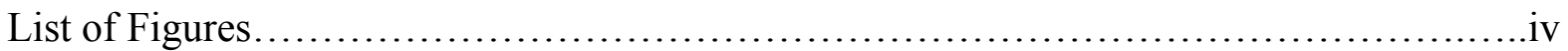

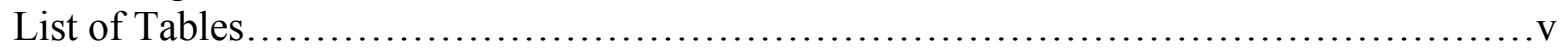

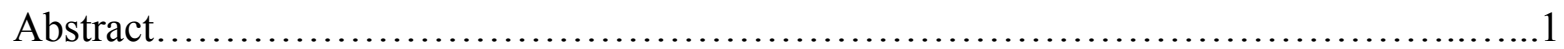

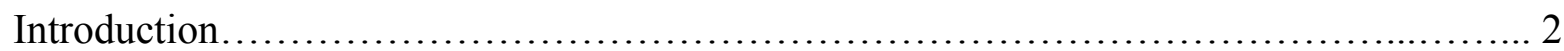

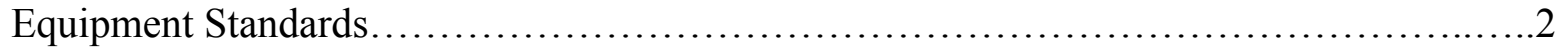

Description of the Thermal Environment.............................................. 5

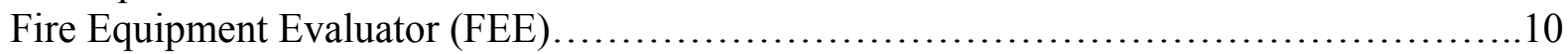

Equipment Testing...................................................................

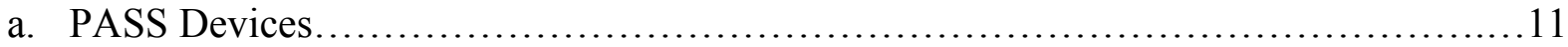

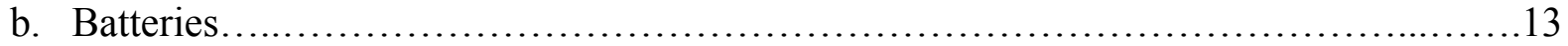

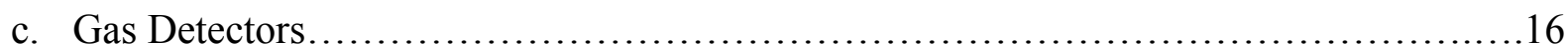

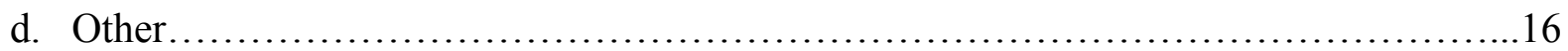

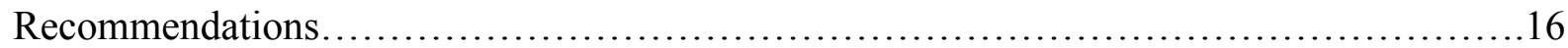

a. Thermal Classes......................................................................

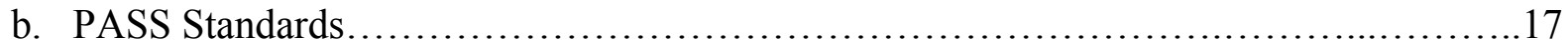

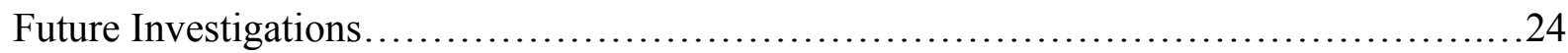

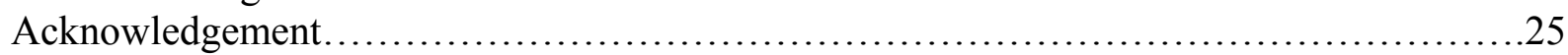

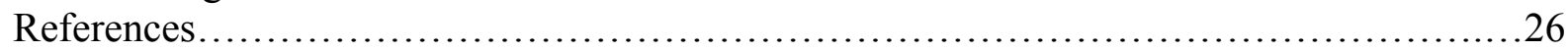

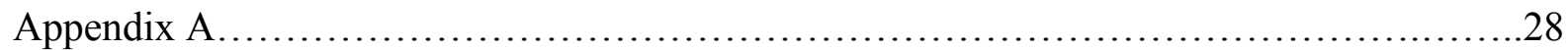

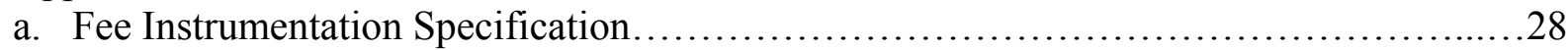




\section{List of Figures}

Figure 1 Thermal protection provided by current firefighters' thermal protective clothing ensembles.

Figure 2 Relative response for $\mathrm{dBA}, \mathrm{dBB}$, and $\mathrm{dBC}$ filters.................................................... 11

Figure 3 Ham Hock A ........................................................................................................ 19

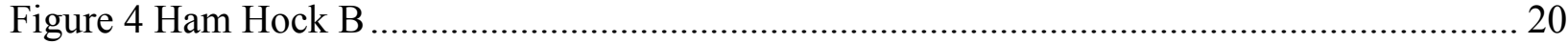

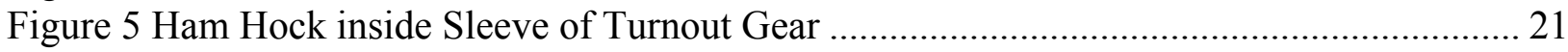

Figure 6 Temperature/time for Ham Hock A.............................................22

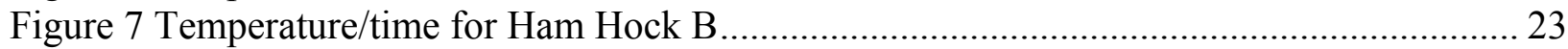

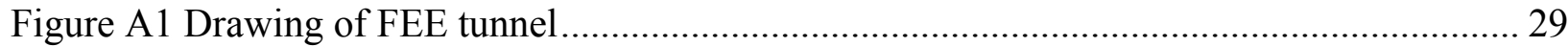

Figure A2 Temperature Profiles near the Back Wall at a Nominal Velocity $0.9 \mathrm{~m} / \mathrm{s}$.................. 31

Figure A3 Temperature Profiles at the Center of the Duct at a Nominal Velocity $0.9 \mathrm{~m} / \mathrm{s}$........... 31

Figure A4 Temperature Profiles near the Door at a Nominal Velocity $0.9 \mathrm{~m} / \mathrm{s}$.......................... 32

Figure A5 Temperature Profiles near the Back Wall at a Nominal Velocity $1.4 \mathrm{~m} / \mathrm{s}$................. 32

Figure A6 Temperature Profiles near the Center of the Duct at a Nominal Velocity $1.4 \mathrm{~m} / \mathrm{s}$......33

Figure A7 Temperature Profiles near the Door at a Nominal Velocity $1.4 \mathrm{~m} / \mathrm{s}$........................... 33

Figure A8 Temperature Profiles near the Back Wall at a Nominal Velocity $1.9 \mathrm{~m} / \mathrm{s}$.................. 34

Figure A9 Temperature Profiles near the Center of the Duct at a Nominal Velocity $1.9 \mathrm{~m} / \mathrm{s}$...... 34

Figure A10 Temperature Profiles near the Door at a Nominal Velocity $1.9 \mathrm{~m} / \mathrm{s}$......................... 35

Figure A11 Photograph of FEE tunnel and operator Michael Selepak. ……………………...... 36

Figure A12 Photograph of FEE test section and data program ................................................... 36 


\section{List of Tables}

Table 1 Thermal Class I..............................................................

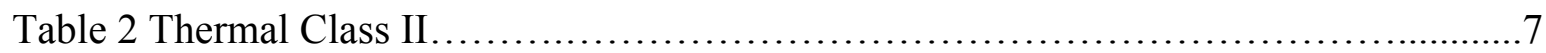

Table 3 Thermal Class III........................................................ 8

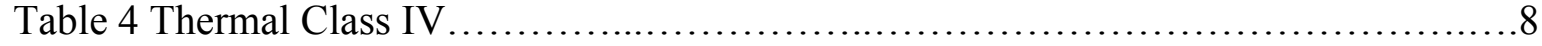

Table 5 Observed Sound Decrease with Temperature.................................. 12

Table 6 Sound Decrease of PASS II with Temperature...................................13

Table 7 PASS with Battery at Ambient Temperature................................... 13

Table 8 Time Test for Battery A at Ambient Temperature..............................14

Table 9 First Temperature/Time Test for Battery A................................ 14

Table 10 Second Temperature/Time Test for Battery A..................................15

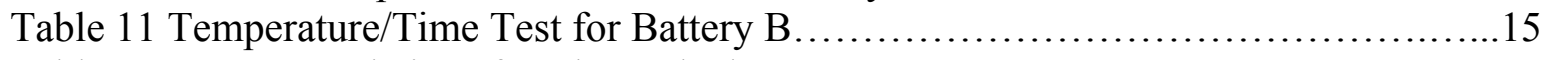

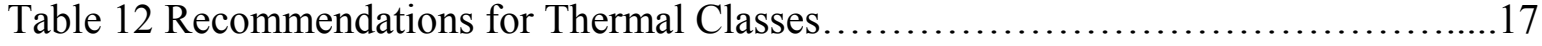

Table 13 Ham Hock Dimensions..................................................... 18 


\title{
Thermal Environment for Electronic Equipment Used by First Responders
}

\author{
M. K. Donnelly, W. D. Davis, J. R. Lawson, and M. J. Selepak
}

\begin{abstract}
The increased use of electronic equipment by emergency responders where that equipment may be repeatedly exposed to elevated temperature, humidity and smoke conditions requires an examination of current manufacturing tests and standards used to certify this equipment. This paper provides a review of the current equipment standards for electronic equipment used by firefighters and other first responders. A thermal classification method is developed based on the protective characteristics of firefighter turn-out gear that should serve as the basis for developing thermal standards for electronic devices used by first responders. The Fire Equipment Evaluator (FEE) that was constructed to investigate the performance of electronic equipment in simulated fire conditions will be described. Results of testing the Personal Alert Safety System (PASS) are presented along with recommendations for revised standards for PASS.
\end{abstract}

Key words: fire fighters; protective clothing; burns (injuries); heat flux; sensors; temperature measurements; test methods; thermal properties; PASS 


\title{
Thermal Environment for Electronic Equipment Used by First Responders
}

\author{
M. K. Donnelly, W. D. Davis, J. R. Lawson, and M. J. Selepak
}

\section{Introduction}

Firefighters and other first responders often operate in adverse building fire environments. Fire environments can expose the responders and their equipment to high temperatures, high humidity, severe thermal radiation and smoky conditions. These adverse conditions can be catastrophic to the normal operation of electronic equipment. The purpose of this project is to examine current standards applied to electronic equipment used by firefighters to ensure that these devices are designed to operate under emergency conditions. Where applicable, the project will identify the need and provide the scientific basis for the development of new equipment standards and test methods. Preliminary research for this project involved three tasks. The first task was to survey the electronic equipment used by firefighters and determine the current standards and guidelines being used. The second task was to research typical thermal environments to which the firefighters, and thus their equipment, are routinely exposed in order to determine conditions for designing the test apparatus. The third task was to develop the test apparatus that would provide a controlled environment that simulates realistic conditions during firefighting.

In the subsequent sections of the paper, the current equipment standards for electronic equipment used by firefighters and other first responders will be described, fire conditions in which this equipment must operate will be defined, the test apparatus to simulate these conditions will be described, and initial results of equipment testing will be presented.

\section{Equipment Standards}

First responders use a variety of electronic equipment to assist them with their response to emergencies. Electronic location devices are useful in tracking the position of firefighters inside a burning structure. A Personal Alert Safety System (PASS) is an electronic device that emits audible alarms to notify others of the location of a downed firefighter. Portable radios have gained much popularity for use by first responders. The radios can be used as both communication devices and also as location devices. Communication sets for wideband ad hoc networks are now in the development stage, but may become important location devices for firefighters in the near future. Other electronic devices used by firefighters include thermal imaging cameras, gas detectors, thermal detectors, and voice amplifiers.

The National Fire Protection Association (NFPA) publishes a series of National Fire Codes, which provide standards and recommendations for the fire service. The NFPA does not participate in enforcing these codes. That is left to the individual fire departments, local and state authorities.

The NFPA standard regarding structural firefighter protective clothing is NFPA 1971 Standard on Protective Ensemble for Structural Fire Fighting [1]. This standard covers all wearable 
elements of the ensemble including helmets, hoods, gloves, footwear, coats and other protective garments. This standard is useful as a reference because it lists temperatures and heat flux levels the firefighter ensemble is designed to protect against. This can provide a guide to the upper bounds of what a firefighter may safely encounter. Chapter 6-6 in NFPA 1971 [1] outlines the heat resistance test for the protective garments. In these tests, the garments must withstand a temperature of $260^{\circ} \mathrm{C}\left(500^{\circ} \mathrm{F}\right)$ for 5 minutes without igniting, melting, dripping or separating. Chapter 6-9 [1] covers the radiant heat resistance test for footwear. In this test the footwear is exposed to $10 \mathrm{~kW} / \mathrm{m}^{2}$ for 1 minute. The thermal exposure for the other protective garments is much higher, as described in the Thermal Protective Performance Test, Chapter 6-10 [1]. The gloves, hoods, wristlets and multilayer protective garment composites are exposed to a total heat flux of $83 \mathrm{~kW} / \mathrm{m}^{2}$ for $30 \mathrm{~s}$, which represents a flashover fire environment.

NFPA 1500, Standard on Fire Department Occupational Safety and Health Program, Chapter 713 [2], requires firefighters to activate Personal Alert Safety Systems (PASS) "in all emergency situations that could jeopardize that person's safety due to atmospheres that could be IDHL ${ }^{1}$, incidents that could result in entrapment, structural collapse of any type, or as directed by the incident commander or incident safety officer." NFPA 1500, Chapter 7.13 [2] also states that the PASS devices comply with NFPA 1982 Standard on Personal Alert Safety Systems (PASS) [3] and that these devices be tested weekly and maintained as instructed by the manufacturer. In accordance with the NFPA standard, most fire departments have regulations requiring firefighters to wear PASS devices when using Self-Contained Breathing Apparatus (SCBA) and in other emergency situations.

The PASS devices are the only electronic equipment with a specific and detailed NFPA standard regarding testing and performance of the apparatus. NFPA 1982 [3] is a comprehensive document concerning standards and performance requirements for the PASS devices including an entire chapter on test requirements. Chapter 6-11 of NFPA 1982 details the heat resistance test for the PASS devices. It requires the PASS devices to function properly after exposure for 5 min at a temperature of $260^{\circ} \mathrm{C}\left(500^{\circ} \mathrm{F}\right)$. This is the same temperature requirement given in NFPA 1971 [1] for protective clothing ensemble. A heat and flame test for PASS devices is described in Chapter 6-12 of NFPA 1982 [3].

Some PASS devices are equipped with thermal detectors which can cause an alarm when a firefighter experiences an extreme temperature, or has spent a long time at a lower temperature threshold. The thermal performance of these thermal sensors is being investigated by NIST researchers [Bryner et al. 2002] [4]. When thermal detectors operate as part of a PASS device, they are subject to NFPA 1982 [3].

The only other electronic equipment groups addressed by NFPA standards are two-way mobile communication equipment and two-way portable communication equipment. The devices are included in the NFPA 1221 standard for Installation, Maintenance and Use of Emergency Services Communications Systems [5]. Sections 8.3.5 and 8.3.6 summarize general equipment usage. The only requirements pertaining to the fire environment are clause 8.3.5.4, which states

\footnotetext{
${ }^{1}$ Immediately Dangerous to Health or Life (IDHL). Any condition that would do one of the following: (a) Pose an immediate or delayed threat to life; (b) Cause irreversible adverse health effects; (c) Interfere with an individual's ability to escape unaided from a hazardous environment. (NFPA 1670: 1.3)
} 
"Mobile radios and associated equipment shall be manufactured for the environment in which they are to be used", and clause 8.3.6.2 which states "Portable radios shall be manufactured for the environment in which they are to be used and shall be of a size and construction to allow their operation with the use of one hand." No specifications for the "environment" are given, and no test procedures or performance criteria are outlined.

The NFPA standards for portable radios are not specific, but many of the manufacturers listed guidelines or specifications to which their equipment adhered. For instance, some manufactures have radios that are used as accessories to Self-Contained Breathing Apparatus (SCBA), and as such these conformed to NFPA 1981 Standard regarding open-circuit SCBA [6]. Some of the manufacturers used the military specification MIL-STDF 810 testing procedure [7]. This specification provides a procedure for testing at a temperature and moisture level; however, these levels are selected by the manufacturer. The temperatures selected for the testing were not near that of a fire environment and were as low as $60^{\circ} \mathrm{C}\left(140^{\circ} \mathrm{F}\right)$.

The emerging technology of the wireless, wideband "ad hoc" networks hopes to provide critical information regarding the location of firefighters inside buildings. Because this technology is still developing, no specific standards exist governing this equipment. Many of the developers indicated that their devices would eventually be embedded in current firefighting equipment, such as SCBA or PASS, and would therefore conform to any NFPA standards for that equipment. The ad hoc networks will be dependent on signal routers strategically placed inside the buildings in order to relay signals and determine a firefighter's position in the building. The routers are to be left unattended, either as permanent fixtures in the building or as temporary "bread crumbs" left behind by the responders moving through the building. The routers will have to be built to very rugged standards since they could be unattended in the path of a fire.

None of the manufacturers of the wireless ad hoc network equipment had any thermal environment performance standards in place. All of the equipment is still in the prototype stage and has not been tested for functionality in the thermal environment. None of the manufactures were designing for the NFPA 1981 SCBA [6] or 1982 PASS [3] requirements at this time.

The thermal imaging camera is a relatively new technology that has become very widespread in the past few years. There are no NFPA standards or other independent standards governing thermal imaging cameras. The performance guidelines for thermal imaging cameras are chosen by the individual manufacturers and are product specific. Individual manufacturers set their own operational heat ratings which ranged from a low of $70^{\circ} \mathrm{C}\left(158^{\circ} \mathrm{F}\right)$ to a high of $450{ }^{\circ} \mathrm{C}\left(842^{\circ} \mathrm{F}\right)$. One manufacturer conformed to the NFPA 1982 PASS standard for heat and flame exposure [3].

Occasionally, electronic gas detectors are used by firefighters to determine the presence of hazardous or life threatening gases in an area. As with the cameras, there are no standards regarding the operation of these devices. The specifications for the gas detectors are selected by the manufacturer. Most conform to the UL 913 Intrinsic Safe standard [8]. All of the detectors investigated claimed to operate in environments up to $50{ }^{\circ} \mathrm{C}\left(122^{\circ} \mathrm{F}\right)$. Some had relative humidity ratings between $90 \mathrm{P} \%$ and $95 \%$, while others were simply deemed "moisture resistant". 


\section{Description of the Thermal Environment}

The advent of the new equipment and technology has greatly improved the personal protective gear worn by firefighters. The disadvantage to this is that firefighters are now able to enter more dangerous conditions than they previously did and this can mean more risks and dangers to the firefighters. Firefighters may be relying more heavily on their technology to warn them of dangers they cannot "feel" and to safeguard them in the event of an emergency. The equipment may be subjected to more dangerous conditions than in the past and a heavier reliance on the equipment calls for a better understanding of its limits. To prepare a test protocol for the equipment, information regarding the thermal environment encountered by firefighters was needed. Much of the information available is based on data collected during firefighter training scenarios and full-scale fire experiments. During actual emergencies, the focus is on saving lives and suppressing fires, not collecting data.

Actual fires produce different thermal environments based on various factors including the initial environment, the ignition source, the combination and arrangement of fuel, ventilation, etc. Many have used a simplified way to classify the thermal environment based on the resulting temperature and heat flux. Several researchers have taken a similar route of designating thermal classes, using temperature and flux ranges to describe the thermal environment within each class. Tables 1 - 4 summarize the thermal environments that researchers and groups have developed. As shown in the tables, the researchers designated either three or four distinct thermal classes, each with a different description and length of time during which a firefighter was expected to function within that class.

Among the first to define thermal classes based on temperature and heat flux was Ordinanz [9] who defined three thermal classes. This analysis was applied to firefighter clothing by Abbott and Schulman [10] and Coletta [11]. The International Association of Firefighters (IAFF) prepared a set of four thermal classes based on Abeles work [12] as part of their Project FIRES report [13]. In 1992, the Federal Emergency Management Agency (FEMA) published a report that included their recommendations for thermal classes as a function of temperature and heat flux [14]. Studies conducted by Foster and Roberts in 1995 (Fire Research and Development Group, FRDG) represent relatively recent work associated with the evaluation of firefighting environments [15]. This study also divided firefighting environments into four conditions: routine, hazardous, extreme, and critical. The results were based on data collected by firefighters outfitted with sensors during fire training scenarios.

The lower thermal classes, Tables 1 and 2, represent the lowest risks for the firefighters but still constitute hazardous working conditions. Firefighters may be exposed to these conditions for extended periods of time, which increases the chance of injury, especially as the protective gear is heated. The presence of moisture makes these conditions worse for firefighters [16]. Electronic equipment carried by firefighters is likely to be exposed to these conditions for extended lengths of time on repeated fire calls. Repeated exposure at seemingly low-impact conditions may cause the electronics to deteriorate overtime.

Thermal Class III shown in Table 3 describes dangerous conditions that a firefighter may encounter fighting a large fire. The firefighter would possibly be exposed to these conditions 
after long time durations in the lower classes. Electronic equipment would be expected to work in this environment after being preheated in the less intense environments. This class represents the upper limit for normal operation by a firefighter.

Thermal Class IV in Table 4 represents the most severe conditions and is characterized by elevated temperatures and fluxes typical of what would be expected in flashover. These are emergency conditions that would not normally be encountered by a firefighter, but may be experienced if the firefighter is caught in a rapidly deteriorating situation. They could only be tolerated for seconds before the firefighter would need to leave the area, or succumb to the intense heat. It is likely that most electronic equipment would fail if under these conditions for any length of time.

The thermal classes are useful for categorizing the increasing risk to firefighters as a function of time, temperature, and heat flux. They provide guidelines for the typical times firefighters may be subjected to these conditions. But the thermal classes illustrate discrepancies between experts regarding the criteria for the different levels, and designations such as "ordinary" and "hazardous" leave room for interpretation. The researchers did not always specify what data were used to make their determinations.

The most severe fire conditions encountered in residential and commercial fires not involving explosions are conditions where a room or rooms are in flashover. The heat release rate required for flashover of the standard international room (ISO 9705) is about $1700 \mathrm{~kW}$ [17] and the flow of hot gases from the doorway or window may exceed $400{ }^{\circ} \mathrm{C}\left(752^{\circ} \mathrm{F}\right)$ [18]. NIST experiments show that in the flashover environment, gas temperatures in the room may reach $1000{ }^{\circ} \mathrm{C}$ $\left(1832^{\circ} \mathrm{F}\right)$ and heat flux at the floor can measure $170 \mathrm{~kW} / \mathrm{m}^{2}$.

Significant temperatures and fluxes can occur even for rooms not at flashover. Quintiere investigated heat fluxes several meters from the doorway of a room containing a fire not at flashover [19]. Fluxes as high as $4.5 \mathrm{~kW} / \mathrm{m}^{2}$ were measured. In tests conducted on firefighters by Foster and Roberts, they found that a flux level of $10 \mathrm{~kW} / \mathrm{m}^{2}$ could only be tolerated by fully equipped firefighters for one minute [15]. They also found that there was damage to the equipment at this flux level.

Experiments by Gross and Fang showed that severe conditions may exist even for low intensity fires, where flame temperatures are about $700^{\circ} \mathrm{C}\left(1292^{\circ} \mathrm{F}\right)[20]$. At the edge of a burning wastebasket they measured heat fluxes of $10 \mathrm{~kW} / \mathrm{m}^{2}$ to $40 \mathrm{~kW} / \mathrm{m}^{2}$ and air temperatures of $100{ }^{\circ} \mathrm{C}$ $\left(212^{\circ} \mathrm{F}\right)$ to $400^{\circ} \mathrm{C}\left(752^{\circ} \mathrm{F}\right)$ at the ceiling above the wastebasket fire.

In addition to the elevated temperatures and heat flux present in a thermal environment, there is often a large amount of humidity, especially if firefighters are using water to suppress the fire. Thermal radiation from the fire changes water flowing from a hose line to water vapor, increasing the humidity. High humidity is of concern for the electronic equipment. Water vapor could enter the instruments and condense inside the electronic elements, adversely impacting their operation. 


\begin{tabular}{|l|l|l|l|}
\hline \multicolumn{1}{|c|}{$\begin{array}{c}\text { Group, } \\
\text { Year }\end{array}$} & Designation & \multicolumn{1}{c|}{ Description } & \multicolumn{1}{c|}{ Ranges } \\
\hline $\begin{array}{l}\text { USFA FEMA, } \\
1992\end{array}$ & None & & \\
\hline $\begin{array}{l}\text { Abeles } \\
\text { Project Fires } \\
1980\end{array}$ & Class 1 & Up to $30 \mathrm{~min}$ & $\begin{array}{l}\text { Temperature to } 40^{\circ} \mathrm{C}\left(104^{\circ} \mathrm{F}\right) \\
\text { Flux to } 0.5 \mathrm{~kW} / \mathrm{m}^{2}\end{array}$ \\
\hline $\begin{array}{l}\text { IAFF } \\
\text { (Based on } \\
\text { Abeles), } 1985\end{array}$ & Class1 & Up to $30 \mathrm{~min}$ & $\begin{array}{l}\text { Temperature to } 40^{\circ} \mathrm{C}\left(104^{\circ} \mathrm{F}\right) \\
\text { Flux to } 0.5 \mathrm{~kW} / \mathrm{m}^{2}\end{array}$ \\
\hline $\begin{array}{l}\text { Foster and } \\
\text { Roberts, } \\
\text { FRDG, } 1995\end{array}$ & Routine & $\begin{array}{l}\text { Elevated temperature, no } \\
\text { direct thermal radiation, } \\
25 \text { min }\end{array}$ & $\begin{array}{l}\text { Temperature to } 100^{\circ} \mathrm{C}\left(212^{\circ} \mathrm{F}\right) \\
\text { Flux to } 1.0 \mathrm{~kW} / \mathrm{m}^{2}\end{array}$ \\
\hline $\begin{array}{l}\text { Coletta, } \\
1976\end{array}$ & None & None & $\begin{array}{l}\text { Abbott, } \\
1976\end{array}$
\end{tabular}

Table 2

Thermal Class II

\begin{tabular}{|c|c|c|c|}
\hline $\begin{array}{l}\text { Group, } \\
\text { Year }\end{array}$ & Designation & Description & Ranges \\
\hline $\begin{array}{l}\text { USFA FEMA, } \\
1992\end{array}$ & Routine & One or two objects burning & $\begin{array}{l}\text { Temperature } 20^{\circ} \mathrm{C}\left(68^{\circ} \mathrm{F}\right) \text { to } \\
60{ }^{\circ} \mathrm{C}\left(140{ }^{\circ} \mathrm{F}\right) \\
\text { Flux } 1.0 \mathrm{~kW} / \mathrm{m}^{2} \text { to } 2.1 \mathrm{~kW} / \mathrm{m}^{2}\end{array}$ \\
\hline $\begin{array}{l}\text { Abeles } \\
\text { Project Fires } \\
1980\end{array}$ & Class 2 & $\begin{array}{l}\text { Small fire in a room, } \\
15 \mathrm{~min}\end{array}$ & $\begin{array}{l}\text { Temperature } 40{ }^{\circ} \mathrm{C}\left(104{ }^{\circ} \mathrm{F}\right) \text { to } \\
95{ }^{\circ} \mathrm{C}\left(203{ }^{\circ} \mathrm{F}\right) \\
\text { Flux } 0.5 \mathrm{~kW} / \mathrm{m}^{2} \text { to } 1.0 \mathrm{~kW} / \mathrm{m}^{2}\end{array}$ \\
\hline $\begin{array}{l}\text { IAFF } \\
\text { (Based on } \\
\text { Abeles), } 1985\end{array}$ & Class 2 & $\begin{array}{l}\text { Small fire in a room, } \\
15 \mathrm{~min}\end{array}$ & $\begin{array}{l}\text { Temperature } 40{ }^{\circ} \mathrm{C}\left(100{ }^{\circ} \mathrm{F}\right) \text { to } \\
93{ }^{\circ} \mathrm{C}\left(200{ }^{\circ} \mathrm{F}\right) \\
\text { Flux } 0.5 \mathrm{~kW} / \mathrm{m}^{2} \text { to } 1.0 \mathrm{~kW} / \mathrm{m}^{2}\end{array}$ \\
\hline $\begin{array}{l}\text { Foster and } \\
\text { Roberts, } \\
\text { FRDG, } 1995\end{array}$ & Hazardous & $\begin{array}{l}\text { Elevated temperature and } \\
\text { direct thermal radiation, } \\
10 \text { min }\end{array}$ & $\begin{array}{l}\text { Temperature } 100{ }^{\circ} \mathrm{C}\left(212{ }^{\circ} \mathrm{F}\right) \text { to } \\
160{ }^{\circ} \mathrm{C}\left(320{ }^{\circ} \mathrm{F}\right) \\
\text { Flux } 1.0 \mathrm{~kW} / \mathrm{m}^{2} \text { to } 4.0 \mathrm{~kW} / \mathrm{m}^{2}\end{array}$ \\
\hline $\begin{array}{l}\text { Coletta, } \\
1976\end{array}$ & Routine & $\begin{array}{l}\text { Fighting fires from a } \\
\text { distance }\end{array}$ & $\begin{array}{l}\text { Temperature to } 60^{\circ} \mathrm{C}\left(140{ }^{\circ} \mathrm{F}\right) \\
\text { Flux } 0.4 \mathrm{~kW} / \mathrm{m}^{2} \text { to } 1.25 \mathrm{~kW} / \mathrm{m}^{2}\end{array}$ \\
\hline $\begin{array}{l}\text { Abbott, } \\
1976\end{array}$ & Routine & $\begin{array}{l}\text { Fighting fires from a } \\
\text { distance }\end{array}$ & $\begin{array}{l}\text { Temperature to } 70{ }^{\circ} \mathrm{C}\left(158^{\circ} \mathrm{F}\right) \\
\text { Flux } 0.5 \mathrm{~kW} / \mathrm{m}^{2} \text { to } 1.7 \mathrm{~kW} / \mathrm{m}^{2}\end{array}$ \\
\hline
\end{tabular}




\begin{tabular}{|c|c|c|c|}
\hline $\begin{array}{l}\text { Group, } \\
\text { Year }\end{array}$ & Designation & Description & Ranges \\
\hline $\begin{array}{l}\text { USFA FEMA, } \\
1992\end{array}$ & Ordinary & $\begin{array}{l}\text { Serious fire, next to a room in } \\
\text { flashover } \\
(10 \text { to } 20) \text { min maximum }\end{array}$ & $\begin{array}{l}\text { Temperature } 60{ }^{\circ} \mathrm{C}\left(140^{\circ} \mathrm{F}\right) \text { to } \\
300{ }^{\circ} \mathrm{C}\left(572{ }^{\circ} \mathrm{F}\right) \\
\text { Flux } 2.1 \mathrm{~kW} / \mathrm{m}^{2} \text { to } 25 \mathrm{~kW} / \mathrm{m}^{2}\end{array}$ \\
\hline $\begin{array}{l}\text { Abeles } \\
\text { Project Fires } \\
1980\end{array}$ & Class 3 & $\begin{array}{l}\text { Totally involved fire, } \\
5 \mathrm{~min}\end{array}$ & $\begin{array}{l}\text { Temperature } 95^{\circ} \mathrm{C}\left(203^{\circ} \mathrm{F}\right) \text { to } \\
250{ }^{\circ} \mathrm{C}\left(482{ }^{\circ} \mathrm{F}\right) \\
\text { Flux } 1.0 \mathrm{~kW} / \mathrm{m}^{2} \text { to } 1.75 \mathrm{~kW} / \mathrm{m}^{2}\end{array}$ \\
\hline $\begin{array}{l}\text { IAFF } \\
\text { (Based on } \\
\text { Abeles), } 1985 \\
\end{array}$ & Class 3 & $\begin{array}{l}\text { Totally involved fire, } \\
5 \mathrm{~min}\end{array}$ & $\begin{array}{l}\text { Temperature } 93{ }^{\circ} \mathrm{C}\left(200{ }^{\circ} \mathrm{F}\right) \text { to } \\
260{ }^{\circ} \mathrm{C}\left(500{ }^{\circ} \mathrm{F}\right) \\
\text { Flux } 1.0 \mathrm{~kW} / \mathrm{m}^{2} \text { to } 1.75 \mathrm{~kW} / \mathrm{m}^{2}\end{array}$ \\
\hline $\begin{array}{l}\text { Foster and } \\
\text { Roberts, } \\
\text { FRDG, } 1995\end{array}$ & Extreme & $\begin{array}{l}\text { Rescue, retreat from flashover } \\
\text { or backdraft }\end{array}$ & $\begin{array}{l}\text { Temperature } 160{ }^{\circ} \mathrm{C}\left(320^{\circ} \mathrm{F}\right) \text { to } \\
235^{\circ} \mathrm{C}\left(455^{\circ} \mathrm{F}\right) \\
\text { Flux } 4.0 \mathrm{~kW} / \mathrm{m}^{2} \text { to } 10.0 \mathrm{~kW} / \mathrm{m}^{2}\end{array}$ \\
\hline $\begin{array}{l}\text { Coletta, } \\
1976\end{array}$ & Hazardous & $\begin{array}{l}\text { Outside burning room or } \\
\text { small building }\end{array}$ & $\begin{array}{l}\text { Temperature } 60{ }^{\circ} \mathrm{C}\left(140{ }^{\circ} \mathrm{F}\right) \text { to } \\
300{ }^{\circ} \mathrm{C}\left(572{ }^{\circ} \mathrm{F}\right) \\
\text { Flux } 1.25 \mathrm{~kW} / \mathrm{m}^{2} \text { to } 8.3 \mathrm{~kW} / \mathrm{m}^{2}\end{array}$ \\
\hline $\begin{array}{l}\text { Abbott, } \\
1976\end{array}$ & Ordinary & $\begin{array}{l}\text { Outside burning room or } \\
\text { small building }\end{array}$ & $\begin{array}{l}\text { Temperature } 70{ }^{\circ} \mathrm{C}\left(158^{\circ} \mathrm{F}\right) \text { to } \\
300{ }^{\circ} \mathrm{C}\left(572{ }^{\circ} \mathrm{F}\right) \\
\text { Flux } 1.7 \mathrm{~kW} / \mathrm{m}^{2} \text { to } 12.5 \mathrm{~kW} / \mathrm{m}^{2}\end{array}$ \\
\hline
\end{tabular}

Table 4

Thermal Class IV

\begin{tabular}{|c|c|c|c|}
\hline $\begin{array}{l}\text { Group, } \\
\text { Year }\end{array}$ & Designation & Description & Ranges \\
\hline $\begin{array}{l}\text { USFA FEMA, } \\
1992\end{array}$ & Emergency & $\begin{array}{l}\text { Severe and unusual, } \\
15 \text { to } 30 \text { s for escape }\end{array}$ & $\begin{array}{l}\text { Temperature } 300{ }^{\circ} \mathrm{C}\left(572{ }^{\circ} \mathrm{F}\right) \text { to } \\
1000{ }^{\circ} \mathrm{C}\left(1832{ }^{\circ} \mathrm{F}\right) \\
\text { Flux } 25 \mathrm{~kW} / \mathrm{m}^{2} \text { to } 125 \mathrm{~kW} / \mathrm{m}^{2}\end{array}$ \\
\hline $\begin{array}{l}\text { Abeles } \\
\text { Project Fires } \\
1980\end{array}$ & Class 4 & $\begin{array}{l}\text { Flashover or backdraft, up } \\
\text { to } 10 \mathrm{~s}\end{array}$ & $\begin{array}{l}\text { Temperature } 250{ }^{\circ} \mathrm{C}\left(482^{\circ} \mathrm{F}\right) \text { to } \\
815^{\circ} \mathrm{C}\left(1500{ }^{\circ} \mathrm{F}\right) \\
\text { Flux } 1.75 \mathrm{~kW} / \mathrm{m}^{2} \text { to } 42 \mathrm{~kW} / \mathrm{m}^{2}\end{array}$ \\
\hline $\begin{array}{l}\text { IAFF } \\
\text { (Based on } \\
\text { Abeles), } 1985\end{array}$ & Class 4 & $\begin{array}{l}\text { Flashover or backdraft, up } \\
\text { to } 10 \mathrm{~s}\end{array}$ & $\begin{array}{l}\text { Temperature } 260{ }^{\circ} \mathrm{C}\left(500{ }^{\circ} \mathrm{F}\right) \text { to } \\
815{ }^{\circ} \mathrm{C}\left(1500{ }^{\circ} \mathrm{F}\right) \\
\text { Flux } 1.75 \mathrm{~kW} / \mathrm{m}^{2} \text { to } 42 \mathrm{~kW} / \mathrm{m}^{2}\end{array}$ \\
\hline $\begin{array}{l}\text { Foster and } \\
\text { Roberts, } \\
\text { FRDG, } 1995\end{array}$ & Critical & $\begin{array}{l}\text { Could be encountered } \\
\text { briefly }\end{array}$ & $\begin{array}{l}\text { Temperature } 235^{\circ} \mathrm{C}\left(455^{\circ} \mathrm{F}\right) \text { to } \\
1000{ }^{\circ} \mathrm{C}\left(1832{ }^{\circ} \mathrm{F}\right) \\
\text { Flux } 10 \mathrm{~kW} / \mathrm{m}^{2} \text { to } 100 \mathrm{~kW} / \mathrm{m}^{2}\end{array}$ \\
\hline $\begin{array}{l}\text { Coletta, } \\
1976\end{array}$ & Emergency & $\begin{array}{l}\text { Not normally encountered, } \\
\text { may be during flashover }\end{array}$ & $\begin{array}{l}\text { Temperature } 300{ }^{\circ} \mathrm{C}\left(572{ }^{\circ} \mathrm{F}\right) \text { to } \\
1000{ }^{\circ} \mathrm{C}\left(1832{ }^{\circ} \mathrm{F}\right) \\
\text { Flux } 8.3 \mathrm{~kW} / \mathrm{m}^{2} \text { to } 105 \mathrm{~kW} / \mathrm{m}^{2}\end{array}$ \\
\hline $\begin{array}{l}\text { Abbott, } \\
1976\end{array}$ & Emergency & $\begin{array}{l}\text { Not normally encountered, } \\
\text { may be during flashover }\end{array}$ & $\begin{array}{l}\text { Temperature } 300^{\circ} \mathrm{C}\left(572^{\circ} \mathrm{F}\right) \text { to } \\
1100{ }^{\circ} \mathrm{C}\left(2012^{\circ} \mathrm{F}\right) \\
\text { Flux } 12.5 \mathrm{~kW} / \mathrm{m}^{2} \text { to } 208 \mathrm{~kW} / \mathrm{m}^{2}\end{array}$ \\
\hline
\end{tabular}


Note:

In Table 4, it is observed that the values from Abeles Project Fires study have been slightly altered by the IAFF classification system. This was apparently done in order to round off values on the Fahrenheit $\left({ }^{\circ} \mathrm{F}\right)$ temperature scale. All numbers in the IAFF classification system were rounded to the nearest $100^{\circ} \mathrm{F}$ value.

An example of changing thermal exposures associated with a transition to flashover conditions is shown in Figure 1 [21]. Since firefighters are normally wearing thermal protective clothing while firefighting, and firefighting tactics are designed to help protect the firefighter from dangerous thermal exposures, the human skin does not immediately experience high temperatures when their protective ensembles are challenged by sudden changes in fire dynamics. The data plots in Figure 1 provide some insight into the degree of thermal protection provided by current day firefighters' thermal protective clothing. These data were generated at NIST using a gas-fired radiant panel that was producing a radiant heat flux of $2.5 \mathrm{~kW} / \mathrm{m}^{2}$ measured at the front surface of an assembly of fabrics and moisture barrier materials that represent the construction of a typical firefighters' protective garment system. At approximately $160 \mathrm{~s}$, a burner producing a sheet of flames was applied to the garment assembly's surface. This was done to approximate an initiation of a flashover condition. The garment system was allowed to heat with a combined total heat flux of $60 \mathrm{~kW} / \mathrm{m}^{2}$ so that temperature conditions on the inside garment layers could be studied. At the end of the exposure the flames were removed and turned off and a thermal shield was placed between the garment assembly and the radiant panel returning the radiant heat flux level to a nominal level of zero.

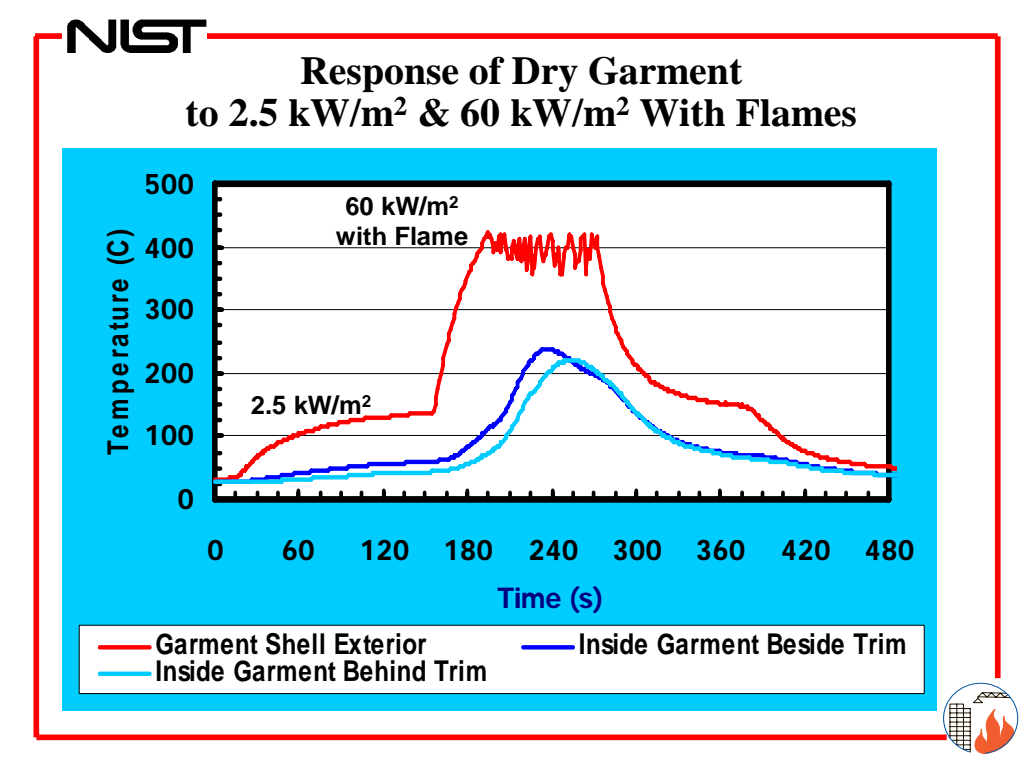

\section{Figure 1 Thermal protection provided by current firefighters' thermal protective clothing ensembles.}

Data plots show that after the initial thermal exposure begins the garment shell temperature gradually increases and remains higher than the temperature inside the garment next to the human skin. This temperature difference varies as the garment system heats and begins to level 
out with a temperature difference of approximately $100^{\circ} \mathrm{C}\left(180^{\circ} \mathrm{F}\right)$. When the flames are added to replicate a flashover condition this temperature difference increases to well over $150{ }^{\circ} \mathrm{C}$ $\left(270^{\circ} \mathrm{F}\right)$. At a point between $250{ }^{\circ} \mathrm{C}\left(482^{\circ} \mathrm{F}\right)$ and $300^{\circ} \mathrm{C}\left(572^{\circ} \mathrm{F}\right)$ temperature conditions on the inside layer of the garment system begin to approach conditions where human skin may feel pain and/or burn injuries may occur. This demonstrates that electronic equipment used by emergency responders and worn on the exterior of firefighters' garments must be able to withstand thermal conditions significantly higher than temperatures that cause human skin burn injuries.

Shell fabrics used in the construction of NFPA 1971 compliant thermal protective ensembles typically do not exhibit thermal damage until they reach temperatures above $300{ }^{\circ} \mathrm{C}\left(572{ }^{\circ} \mathrm{F}\right)$. NFPA 1971 [1] calls for firefighters' protective ensembles to be tested at a thermal exposure of $260{ }^{\circ} \mathrm{C}\left(500^{\circ} \mathrm{F}\right)$ for $5 \mathrm{~min}$. This thermal requirement was primarily selected to help eliminate garment materials that would melt and drip or stick to human skin during challenging thermal exposures while firefighting operations are underway, and it was designed to insure a minimum level of performance so that garment systems would maintain their protective properties under this type of exposure.

Since firefighters' personal protective electronic equipment (example: Personal Alert Safety System PASS) and emergency responder communications equipment (example: radio) perform similar life safety functions, it is reasonable to consider using the NFPA 1971 thermal exposure criteria for testing electronic devices that are used in the same firefighting environments [1]. It is equally as important that these electronic devices function at a time when the life of an emergency responder is at great risk.

\section{Fire Equipment Evaluator (FEE)}

A Fire Equipment Evaluator (FEE) was designed and constructed to simulate expected conditions encountered by firefighters up to Thermal Class III fires conditions. Target conditions included being able to reach a temperature of $300^{\circ} \mathrm{C}\left(572{ }^{\circ} \mathrm{F}\right)$ and a total thermal flux of $20 \mathrm{~kW} / \mathrm{m}^{2}$. The $20 \mathrm{~kW} / \mathrm{m}^{2}$ value was chosen rather then the $25 \mathrm{~kW} / \mathrm{m}^{2}$ recommended by USFA based on the fact that $20 \mathrm{~kW} / \mathrm{m}^{2}$ is considered the radiation flux at the time of flashover, which is a Thermal Class IV condition. The resulting device is shown in Figure A1. It consists of a stainless steel closed circuit, fan driven, air flow loop $220 \mathrm{~cm}$ long, $174 \mathrm{~cm}$ high, and $38 \mathrm{~cm}$ wide. The current test chamber is $0.91 \mathrm{~m}$ (36 in) long with a $0.38 \mathrm{~m}$ (15 in) square cross section. The test chamber can be expanded to fit larger equipment as needed. Current operating conditions within the test chamber include:

- Flow rates from $0.5 \mathrm{~m} / \mathrm{s}$ to $2.0 \mathrm{~m} / \mathrm{s}$.

- Temperature up to $300{ }^{\circ} \mathrm{C}\left(572^{\circ} \mathrm{F}\right)$.

- Convective Heat Flux up to $16 \mathrm{~kW} / \mathrm{m}^{2}$.

- Radiant Flux up to $4 \mathrm{~kW} / \mathrm{m}^{2}$.

- Gas injection to test gas sensors.

Controlled exposure of the electronics to water and smoke will be added once the initial thermal testing of the firefighter devices is completed. 
Instrumentation for the FEE includes:

- Thermocouples for temperature measurement

- Bi-directional probe for velocity measurement

- Flux gauges oriented to measure both convective and radiant flux

- Sound meter to measure sound intensities

- Real-time spectrum analyzer to measure radio performance

Temperature measurements were made in the test section using an array of five type $\mathrm{K}$ (Chromel-Alumel) thermocouples, each with a bead diameter of $1.0 \pm 0.2 \mathrm{~mm}$. Temperature measurements were conducted both horizontally and vertically with thermocouple arrays that define the temperature distribution in the test chamber. Figures A2 - A10 in Appendix A show the temperature variation in the test chamber as a function of flow velocity. Higher flows yielded a more uniform test environment across the chamber. Temperature measurements from thermocouples are estimated to be within $\pm 1.0^{\circ} \mathrm{C}\left( \pm 2{ }^{\circ} \mathrm{F}\right)$ of the correct temperature. Uncertainties in the flow velocity using the bi-directional probe are estimated to be $\pm 0.2 \mathrm{~m} / \mathrm{s}$. Heat flux measurement uncertainties are estimated to be $\pm 0.2 \mathrm{~kW} / \mathrm{m}^{2}$

\section{Equipment Testing}

\section{a. PASS Devices}

NFPA 1982, the current standard for PASS devices, requires that they provide an alarm at $95 \mathrm{dBA}$ for a spherical radial distance of $3 \mathrm{~m}(9.9 \mathrm{ft})$ [3]. A pre-alarm signal, which sounds for an interval of not more than $13 \mathrm{~s}$, must reach a level of $100 \mathrm{dBA}$ and remain at or above this level for 3 to 5 seconds. A low battery signal that operates for one hour at a sound level between $70 \mathrm{dBA}$ and $100 \mathrm{dBA}$ is also required. The $\mathrm{dBA}$ rating is a sound measurement using a filter that corresponds to the response of the ear for modest sound levels where the ear is fairly insensitive to low frequencies. Figure 2 provides the response curves for $\mathrm{dBA}, \mathrm{dBB}$, and $\mathrm{dBC}$ filters

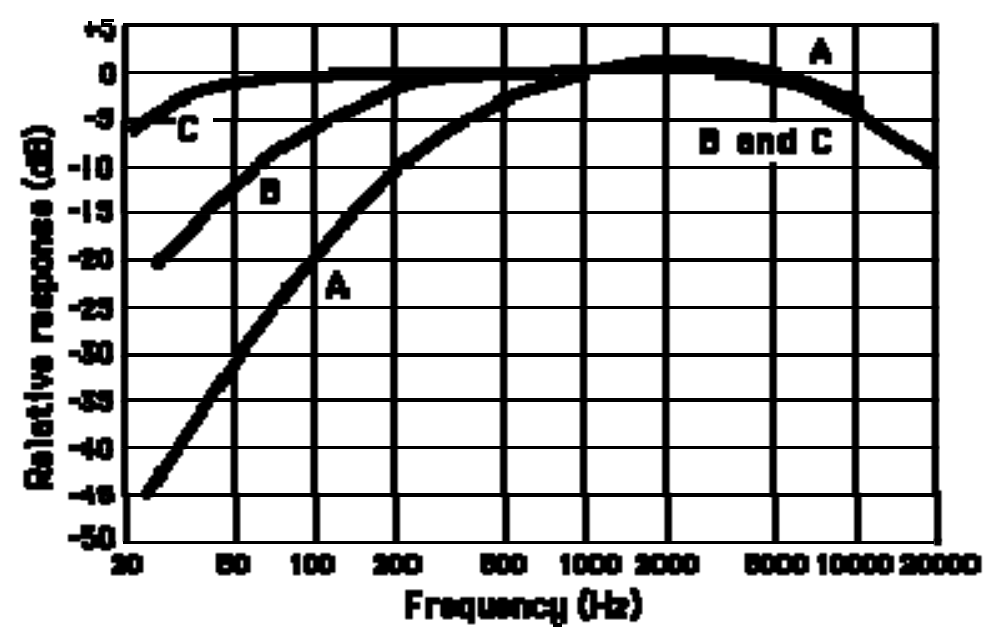

Figure 2 Relative response for $\mathrm{dBA}, \mathrm{dBB}$, and $\mathrm{dBC}$ filters 
The two thermal tests that these devices are required by NFPA 1982 [3] to pass are:

a. Being heated in an oven for $5 \mathrm{~min}$ at a temperature of $260^{\circ} \mathrm{C}\left(500^{\circ} \mathrm{F}\right)$ and then being removed from the oven and tested for the above operations.

b. Being heated in an oven for $15 \mathrm{~min}$ at a temperature of $95^{\circ} \mathrm{C}\left(203^{\circ} \mathrm{F}\right)$ and then exposed to flames for $10 \mathrm{~s}$ at a peak temperature of between $815^{\circ} \mathrm{C}\left(1500{ }^{\circ} \mathrm{F}\right)$ and $1150{ }^{\circ} \mathrm{C}\left(2102^{\circ} \mathrm{F}\right)$ with a mean of $950^{\circ} \mathrm{C}\left(1742^{\circ} \mathrm{F}\right)$.

The purpose of testing the PASS in the FEE was not to test the capability of these devices to conform to the NFPA tests, but to examine conditions that first responders would encounter where a properly functioning PASS device would mean the difference between life and death. Since Thermal Class III conditions represent the most extreme conditions that firefighters would experience for extended lengths of time, it was decided to test the devices under these conditions. Tests were conducted with maximum temperatures of $300^{\circ} \mathrm{C}\left(572{ }^{\circ} \mathrm{F}\right)$ or less for time periods of five or more minutes. A fresh battery was used in the PASS device at the beginning of each test.

PASS devices from two manufacturers (referred in the paper as I and II) were tested in the FEE. Initially, the PASS device was tested by heating the test area in the FEE to $260{ }^{\circ} \mathrm{C}\left(500{ }^{\circ} \mathrm{F}\right)$ and then inserting the PASS for five minutes. The PASS device was removed and the alarm sound was measured within a minute of removal. It was noted that the PASS sounded at lower dBA levels when hot but recovered rapidly as it cooled. Devices from manufacturer I tended to have more problems with melting and deformation due to heating to $260{ }^{\circ} \mathrm{C}\left(500^{\circ} \mathrm{F}\right)$ than from manufacturer II. The devices from Manufacturer I also had a tendency to stop alarming and shut off during the cooling period.

Examples of sound changes experienced by both devices are presented in Table 5. The change in sound intensity is equal to the difference in dBA between the measurements of sound emitted by the device in the FEE when the PASS is at $23{ }^{\circ} \mathrm{C}\left(73^{\circ} \mathrm{F}\right)$ and at an elevated temperature after the specified period of heating. The sound meter was located $7.62 \mathrm{~cm}(3 \mathrm{in})$ from the glass door.

Table 5

Observed Sound Decrease with Temperature

\begin{tabular}{|c|c|c|c|}
\hline PASS Device & $\begin{array}{c}\text { Temperature } \\
\left({ }^{\circ} \mathbf{C}\right) /\left({ }^{\circ} \mathbf{F}\right)\end{array}$ & $\begin{array}{c}\text { Time } \\
(\mathbf{s})\end{array}$ & $\begin{array}{c}\text { Sound Difference } \\
(\mathbf{d B})\end{array}$ \\
\hline I & $260 /(500)$ & 53 & 13 \\
\hline I & $260 /(500)$ & 213 & 14 \\
\hline II & $260 /(500)$ & 300 & 17 \\
\hline II & $200 /(392)$ & 306 & $\mathbf{0}$ \\
\hline II & $150 /(302)$ & 302 & \\
\hline
\end{tabular}

A PASS Device from manufacturer II was subjected to a continuous heating regime up until failure. The results of this test are shown in Table 6. During the initial 5 minutes, as the unit was at a temperature of $100{ }^{\circ} \mathrm{C}\left(212^{\circ} \mathrm{F}\right)$, there was no loss to the sound measurement. But as the temperature was increased, the sound decreased until the device failed. This PASS device recovered after cool down. The scenario simulated here might be a more realistic scenario for a 
firefighter who spends some time in regions of elevated temperature and then encounters a Thermal Class III event.

Table 6 Sound Decrease of a PASS Device from Manufacturer II with Temperature

\begin{tabular}{|c|c|c|}
\hline Temperature $\left({ }^{\circ} \mathrm{C}\right) /\left({ }^{\circ} \mathbf{F}\right)$ & Time (s) & Sound Difference (dB) \\
\hline $23 / 73$ & 0 & 0 \\
\hline $100 / 212$ & 302 & 6 \\
\hline $150 / 302$ & 885 & 14 \\
\hline $200 / 392$ & 1377 & Failure \\
\hline
\end{tabular}

In order to determine if the heating was causing the battery to fail, tests were conducted with the battery powering the PASS device remaining at ambient temperature. The current drawn from the battery to the PASS device was monitored during the heating period. Table 7 summarizes the results of the tests.

Table 7

PASS Device with Battery at Ambient Temperature

\begin{tabular}{|c|c|c|c|c|c|c|}
\hline $\begin{array}{c}\text { PASS } \\
\text { Device }\end{array}$ & $\begin{array}{c}\text { Temperature } \\
\left({ }^{\circ} \mathbf{C}\right) /\left({ }^{\circ} \mathbf{F}\right) \\
\text { at 300 s }\end{array}$ & $\begin{array}{c}\text { Lights } \\
\text { Flashing } \\
(\mathbf{m A})\end{array}$ & $\begin{array}{c}\text { First } \\
\text { Alarm } \\
(\mathbf{m A})\end{array}$ & $\begin{array}{c}\text { Second } \\
\text { Alarm } \\
(\mathbf{m A})\end{array}$ & $\begin{array}{c}\text { Full } \\
\text { Alarm } \\
(\mathbf{m A})\end{array}$ & $\begin{array}{c}\text { Sound } \\
\text { Diff } \\
(\mathbf{d B A})\end{array}$ \\
\hline II & $23 / 73$ & 2 & $16-18$ & $20-46$ & 140 & $\mathbf{0}$ \\
\hline II & $260 / 500$ & 2 & $16-18$ & 40 & $130-144$ & 16 \\
\hline
\end{tabular}

The sound diminished by $16 \mathrm{dBA}$ during the heating test even though the battery remained at ambient temperature.

This PASS device from manufacturer I failed to alarm during this test. The current draw from the flashing lights on the PASS remained a constant $6 \mathrm{~mA}$ to $7 \mathrm{~mA}$ until the unit failed $423 \mathrm{~s}$ into the test.

\section{b. Batteries}

The battery types used in PASS devices were tested to see how they would respond to Thermal Class III fire conditions. It should be noted that the manufacturer's maximum operating temperature for these batteries is $54^{\circ} \mathrm{C}\left(129^{\circ} \mathrm{F}\right)$, far lower than the conditions at which PASS devices are required to operate. Presumably, the PASS outer case and battery compartment is designed to provide thermal protection for the battery. Two types of batteries, A and B, were investigated. To test the batteries for high temperature performance, they were placed in the duct and connected to a $1000 \Omega$ resistor located outside the duct. The current flow and voltage across the resistor were monitored as a function of time and temperature. The capability of battery A was tested under a $1053 \Omega$ load at room temperature, with no heating as shown in Table 8 . The 
battery demonstrated a capability to supply a current of approximately $9 \mathrm{~mA}$ for $5400 \mathrm{~s}$ under this load.

The batteries were then tested at elevated temperatures. Tables 9 and 10 provide the data collected during two tests of type A batteries. The batteries were placed in the tunnel and the air temperature was increased to nominally $260^{\circ} \mathrm{C}\left(500^{\circ} \mathrm{F}\right)$ and then held at that temperature. In both tests, the battery was able to sustain a fairly consistent current level for roughly $600 \mathrm{~s}$ at $260^{\circ} \mathrm{C}\left(500^{\circ} \mathrm{F}\right)$ but would deform and explode within the next $300 \mathrm{~s}$. Table 11 shows the data for the test of battery type B. The current level for this battery began dropping after less than $500 \mathrm{~s}$ of heating at approximately $260^{\circ} \mathrm{C}\left(500^{\circ} \mathrm{F}\right)$ and the voltage and current continued to drop more sharply than the type A batteries as exposure to this elevated temperature continued. This battery was not heated to explosion.

Table 8

Time Test for Battery A at Ambient Temperature

\begin{tabular}{|c|c|}
\hline Time (s) & Voltage (V) \\
\hline 0 & 9.56 \\
\hline 390 & 9.49 \\
\hline 900 & 9.43 \\
\hline 1200 & 9.40 \\
\hline 1500 & 9.37 \\
\hline 1800 & 9.34 \\
\hline 2320 & 9.30 \\
\hline 4200 & 9.16 \\
\hline 4500 & 9.15 \\
\hline 4800 & 9.13 \\
\hline 5400 & 9.10 \\
\hline
\end{tabular}

Table 9

First Temperature/Time Test for Battery A

\begin{tabular}{|c|c|c|c|}
\hline Time (s) & Voltage (V) & Current (mA) & $\begin{array}{c}\text { Temperature } \\
\left({ }^{\circ} \mathbf{C}\right) /\left({ }^{\circ} \text { F }\right)\end{array}$ \\
\hline 0 & 9.45 & 9.00 & $23 / 73$ \\
\hline 160 & 9.40 & 8.96 & $27 / 81$ \\
\hline 300 & 9.39 & 8.95 & $110 / 230$ \\
\hline 480 & 9.38 & 8.94 & $217 / 423$ \\
\hline 660 & 9.35 & 8.90 & $254 / 489$ \\
\hline 780 & 9.36 & 8.92 & $261 / 502$ \\
\hline 960 & 9.35 & 8.91 & $261 / 502$ \\
\hline 1080 & 9.33 & 8.89 & $262 / 504$ \\
\hline 1140 & 9.31 & 8.86 & $262 / 504$ \\
\hline 1200 & 9.23 & 8.82 & $263 / 505$ \\
\hline 1300 & 9.17 & 8.70 & $264 / 507$ \\
\hline 1460 & 8.99 & 8.57 & $261 / 505$ \\
\hline 1660 & 8.87 & 8.45 & $261 / 502$ \\
\hline 1780 & 8.82 & 8.40 & \\
\hline 1810 & Battery Exploded & & \\
\hline
\end{tabular}


Table 10

Second Temperature/Time Test for Battery A

\begin{tabular}{|c|c|c|c|}
\hline Time (s) & Voltage (V) & Current (mA) & $\begin{array}{c}\text { Temperature } \\
\left({ }^{\circ} \mathrm{C}\right) /\left({ }^{\circ} \mathbf{F}\right)\end{array}$ \\
\hline 0 & 9.36 & 8.86 & $23 / 73$ \\
\hline 160 & 9.33 & 8.84 & $27 / 81$ \\
\hline 300 & 9.32 & 8.83 & $112 / 234$ \\
\hline 480 & 9.30 & 8.81 & $218 / 424$ \\
\hline 660 & 9.29 & 8.79 & $253 / 487$ \\
\hline 780 & 9.30 & 8.80 & $256 / 493$ \\
\hline 960 & 9.30 & 8.81 & $260 / 500$ \\
\hline 1080 & 9.27 & 8.78 & $262 / 504$ \\
\hline 1140 & 9.23 & 8.74 & $262 / 504$ \\
\hline 1200 & 9.20 & 8.70 & $261 / 502$ \\
\hline 1320 & 9.07 & 8.59 & $261 / 502$ \\
\hline 1380 & 8.98 & 8.50 & \\
\hline 1440 & Bulging at battery & & \\
\hline 1453 & bottom & & \\
\hline & Battery Exploded & & \\
\hline
\end{tabular}

Table 11

Temperature/Time Test for Battery B

\begin{tabular}{|c|c|c|c|}
\hline Time (s) & Voltage (V) & Current (mA) & $\begin{array}{c}\text { Temperature } \\
\left({ }^{\circ} \mathbf{C}\right) /\left({ }^{\circ} \text { F) }\right.\end{array}$ \\
\hline 110 & 9.23 & 8.80 & $23 / 73$ \\
\hline 180 & 9.22 & 8.79 & $38 / 100$ \\
\hline 300 & 9.21 & 8.77 & $111 / 232$ \\
\hline 480 & 9.19 & 8.75 & $218 / 424$ \\
\hline 660 & 9.17 & 8.73 & $253 / 487$ \\
\hline 780 & 9.17 & 8.74 & $256 / 493$ \\
\hline 960 & 9.20 & 8.76 & $260 / 500$ \\
\hline 1080 & 9.18 & 8.75 & $262 / 504$ \\
\hline 1140 & 8.74 & 8.23 & $262 / 504$ \\
\hline 1200 & 7.70 & 7.31 & $263 / 505$ \\
\hline 1260 & 7.58 & 7.21 & $263 / 505$ \\
\hline 1320 & 7.47 & 7.10 & $257 / 495$ \\
\hline 1440 & 7.29 & 6.94 & $223 / 433$ \\
\hline 1740 & 6.50 & 6.30 & $165 / 329$ \\
\hline 3160 & 4.90 & 4.67 & $23 / 73$ \\
\hline
\end{tabular}




\section{c. Gas Detectors}

The temperature dependence of a hand-held oxygen detector was examined in order to develop some experience with these types of detectors. Since this detector alarms when the oxygen concentration drops below a specified level, a nitrogen purge was set up with a flow meter and solenoid valve that provided a flow of $140 \mathrm{cc} / \mathrm{min}$ of $\mathrm{N}_{2}$ to the oxygen sensor that was sufficient to set off the alarm. The detector was placed in the tunnel and gradually heated. The manufacturer of the detector states that the high temperature operating limit is $50^{\circ} \mathrm{C}\left(122^{\circ} \mathrm{F}\right)$. The measurements in the FEE suggest that the unit performs reliably to $102^{\circ} \mathrm{C}\left(216^{\circ} \mathrm{F}\right)$, which is when the visual display begins to fade. The low oxygen alarm continued to sound at this temperature. In all tests, as the temperature of the unit dropped back to $80^{\circ} \mathrm{C}\left(176^{\circ} \mathrm{F}\right)$, the display recovered and the unit appeared to function normally.

\section{d. Other}

Testing of hand-held radios used by first responders has begun. At this point, there is not enough data to establish the thermal capabilities of these devices. Testing of infrared cameras has not started but will begin in the next phase of the project. It is also planned to test PASS devices that are integrated into Self-Contained Breathing Apparatus, as the thermal response of these devices will be different compared with a stand-alone PASS device.

\section{Recommendations}

\section{a. Thermal Classes}

The concept of Thermal Classes is valuable as it provides temperature - time targets for equipment manufacturers. The issue that needs to be resolved is to define the classes in a manner that is realistic for conditions experienced by firefighters and is also not so broad as to lose its usefulness for equipment manufacturers. The USFA and FEMA defined a three class system while a number of other researchers proposed a four class system. There appears to be an advantage to defining a four class system in that life safety conditions are better defined and breaking the ordinary category defined by USFA and FEMA into two categories provides better definition for the operational capabilities of different electronic equipment.

The proposed four Thermal Class model is presented in Table 12. The rationale for Thermal Class I is based on the analysis of Foster and Roberts (FRDG) [15] for firefighters. It also is appropriate for an equipment standard as it was noted in tests using the FEE that the display for the oxygen detector tended to fail at temperatures just over $100^{\circ} \mathrm{C}\left(212^{\circ} \mathrm{F}\right)$ making devices using these types of displays Thermal Class I devices.

The FRDG recommendation was also used to define Thermal Class II conditions. From an equipment standpoint, this may be the Thermal Class for unprotected emergency radios but additional testing is required in order to understand the failure modes for this type of equipment.

The recommendation for Thermal Class III was based on a number of issues. Because Thermal Class III is a region where firefighters work for a short time $(5 \mathrm{~min})$ and the heat flux must be 
less than $20 \mathrm{~kW} / \mathrm{m}^{2}$, which is considered the onset of flashover, the $10 \mathrm{~kW} / \mathrm{m}^{2}$ value for heat flux was chosen. Work done at NIST has shown that over short exposure times exterior surface temperatures of garments above $100^{\circ} \mathrm{C}$ resulting from $250{ }^{\circ} \mathrm{C}$ air temperatures caused interior garment temperatures of $55^{\circ} \mathrm{C}\left(131^{\circ} \mathrm{F}\right)$ to $60^{\circ} \mathrm{C}\left(140^{\circ} \mathrm{F}\right)$ when human skin inside the garment may feel pain and/or burn. The $260^{\circ} \mathrm{C}\left(500^{\circ} \mathrm{F}\right)$ criteria was selected based on recommendations by FEMA [14], USFA, and IAFF [13] suggesting that firefighters could work for 5 min at this temperature. This temperature also fits nicely with the NFPA 1982 standard for PASS devices [3] and the NFPA 1971 standard for protective ensembles [1].

Table $12 \quad$ Recommendations for Thermal Classes

\begin{tabular}{|c|c|c|c|}
\hline Thermal Class & $\begin{array}{c}\text { Maximum } \\
\text { Time }(\mathrm{min})\end{array}$ & $\begin{array}{c}\text { Maximum } \\
\text { Temperature } \\
\left({ }^{\circ} \mathrm{C}\right) /\left({ }^{\circ} \mathrm{F}\right)\end{array}$ & $\begin{array}{c}\text { Maximum } \\
\text { Flux }\left(\mathrm{kW} / \mathrm{m}^{2}\right)\end{array}$ \\
\hline I & 25 & $100 / 212$ & 1 \\
\hline II & 15 & $160 / 320$ & 2 \\
\hline III & 5 & $260 / 500$ & $>10$ \\
\hline IV & $<1$ & $>260 / 500$ & $>$ \\
\hline
\end{tabular}

Thermal burns to the respiratory tract must be considered when applying the concept of Thermal Class. The moisture content of the heated air is important as dry air must be at least $120{ }^{\circ} \mathrm{C}$ $\left(248^{\circ} \mathrm{F}\right)$ to reach the threshold for burns to the larynx. For humid air, steam, or air containing smoke the threshold for burns to the larynx may drop to $100{ }^{\circ} \mathrm{C}\left(212^{\circ} \mathrm{F}\right)$ [22]. This analysis suggests that firefighters exposed to Thermal Class II or higher conditions must have the appropriate thermal protection to reduce the exposure to that of Thermal Class I conditions.

\section{b. PASS Standards}

Since PASS must work as long as there is potential for rescue, the requirements which PASS must meet will depend on the capability of the firefighter's protective clothing to sustain life in adverse conditions. Since firefighters would not be able to perform search and rescue operations in Thermal Class IV conditions, the PASS standard should be based on Thermal Class III conditions. At issue is the need to determine the length of time that a trapped firefighter could survive in Thermal Class III. Survival in Thermal Class III conditions will depend on the thermal protection of the firefighter's protective clothing, the air capacity of the breathing apparatus, and the extent of any injuries suffered during entrapment or incapacitation.

Experiments were conducted to determine the temperature/time profile that would be experienced by firefighters protected by turnout gear and experiencing Thermal Class III conditions. Since human testing is not acceptable for this Thermal Class, an appropriate simulant was used. The simulant used was a ham hock. The choice was based on research performed by Moritz and Henriques [23] who showed that pig skin was an acceptable simulant for human skin. 
Each ham hock was instrumented with two thermocouples attached by thread to the outside surface of the skin and two attached at the bottom surface of the skin in approximately the same location as the ones affixed to the skin surface. A fifth thermocouple, sewn to the inside surface of the turnout sleeve monitored the temperature of this surface and a sixth thermocouple sewn to the outside surface monitored the outside sleeve temperature. The seventh thermocouple monitored the temperature of the airflow upstream from the end of the sleeve. The sleeve was mounted inside the FEE with the end inside the FEE closed such that no hot air could enter. The sleeve was fed through a hole in the bottom of the FEE with the thermocouple wires exiting through the hole. The physical dimensions of the two ham hocks are given in Table 13.

Table 13 The Physical Dimensions of the Two Ham Hock Tested

\begin{tabular}{|c|c|c|c|c|}
\hline Ham Hock & $\begin{array}{c}\text { Mass } \\
(\mathrm{g})\end{array}$ & $\begin{array}{c}\text { Large Diameter } \\
(\mathrm{cm})\end{array}$ & $\begin{array}{c}\text { Small Diameter } \\
(\mathrm{cm})\end{array}$ & $\begin{array}{c}\text { Length } \\
(\mathrm{cm})\end{array}$ \\
\hline $\mathrm{A}$ & 672.6 & $14.6 \times 7.6$ & $8.6 \times 5.7$ & $13.6 / 7.9$ \\
\hline $\mathrm{B}$ & 599.0 & $15.2 \times 7.6$ & $10.2 \times 5.1$ & $10.2 / 7.6$ \\
\hline
\end{tabular}

Ham hocks have large and small ends which are irregular in diameter. The diameter measurements are in perpendicular directions with the largest diameter given first. Opposite lengths are also given as the distance from end to end varies around the diameter. Pictures of ham hock A and B instrumented with thermocouples are shown in Figures 3 and 4 


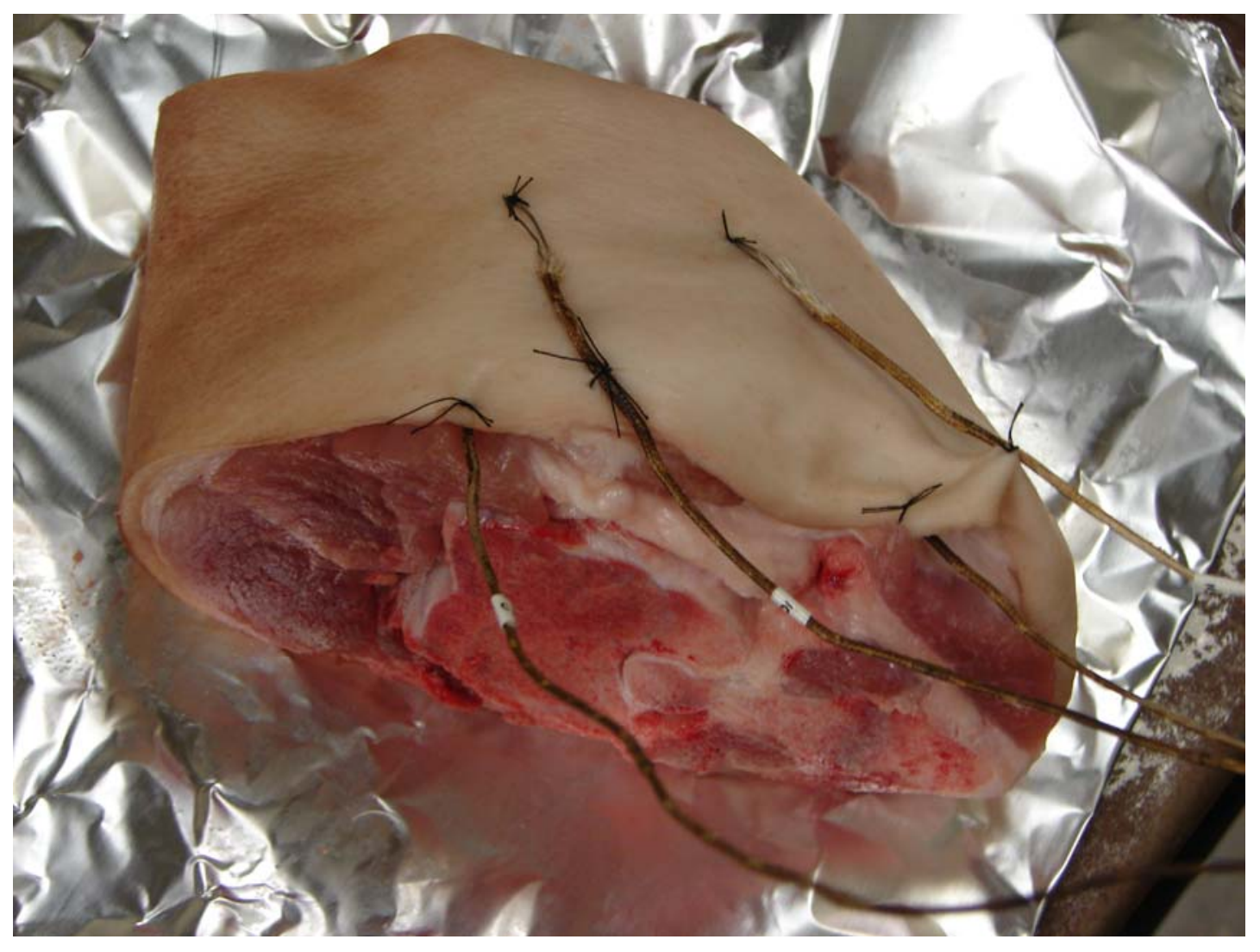

Figure 3 Ham Hock A 


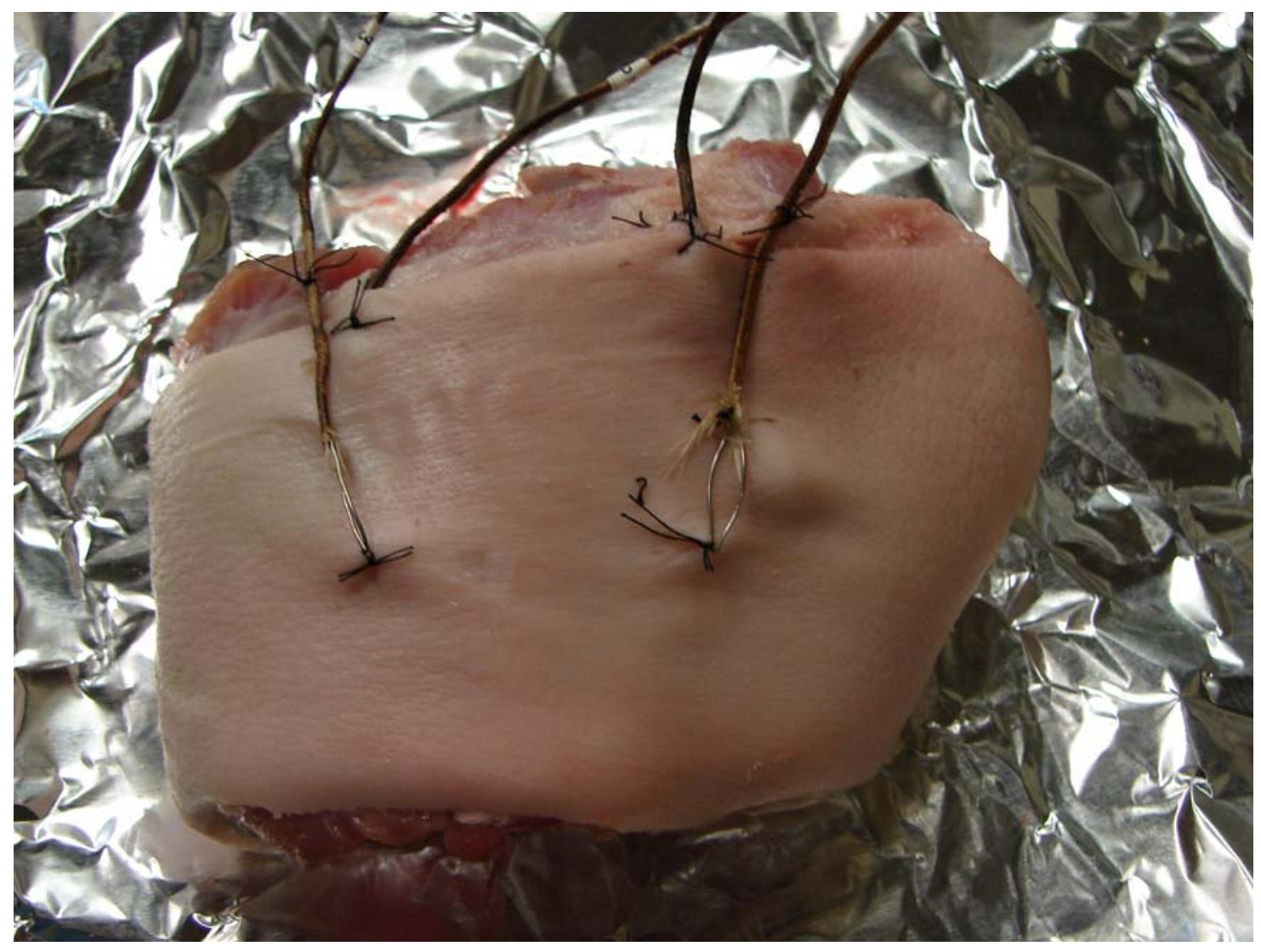

Figure 4 Ham Hock B

The average skin thickness for Ham Hock B at the end of the test was $2.5 \pm 0.4 \mathrm{~mm}$. This is substantially larger than the $0.08 \mathrm{~mm}$ skin depth that was used for developing the $44{ }^{\circ} \mathrm{C}\left(111^{\circ} \mathrm{F}\right)$ target temperature for the onset of skin damage based on work by Moritz and Henriques[23]. Therefore, only surface temperatures will be used in the analysis. Figure 5 shows the orientation of the sleeve in the FEE. 


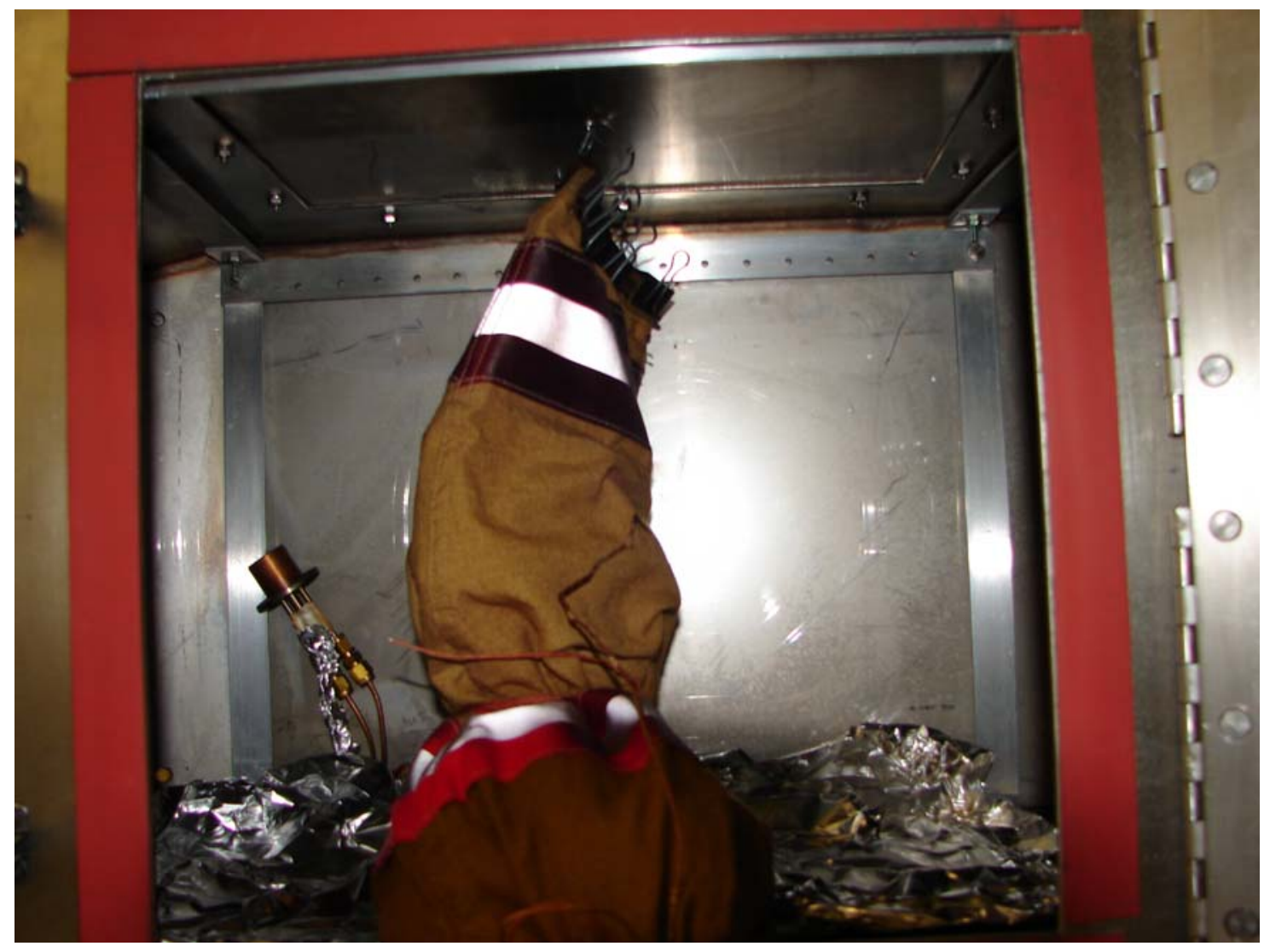

Figure 5 Ham Hock inside Sleeve of Turnout Gear

Figures 6 and 7 present the temperature time history for the two experiments. It took approximately 150 seconds to start the heating from the beginning of the data collection at time zero and 660 seconds to 750 seconds for the flow to reach a steady $260{ }^{\circ} \mathrm{C}\left(500^{\circ} \mathrm{F}\right)$. 
Ham Hock A

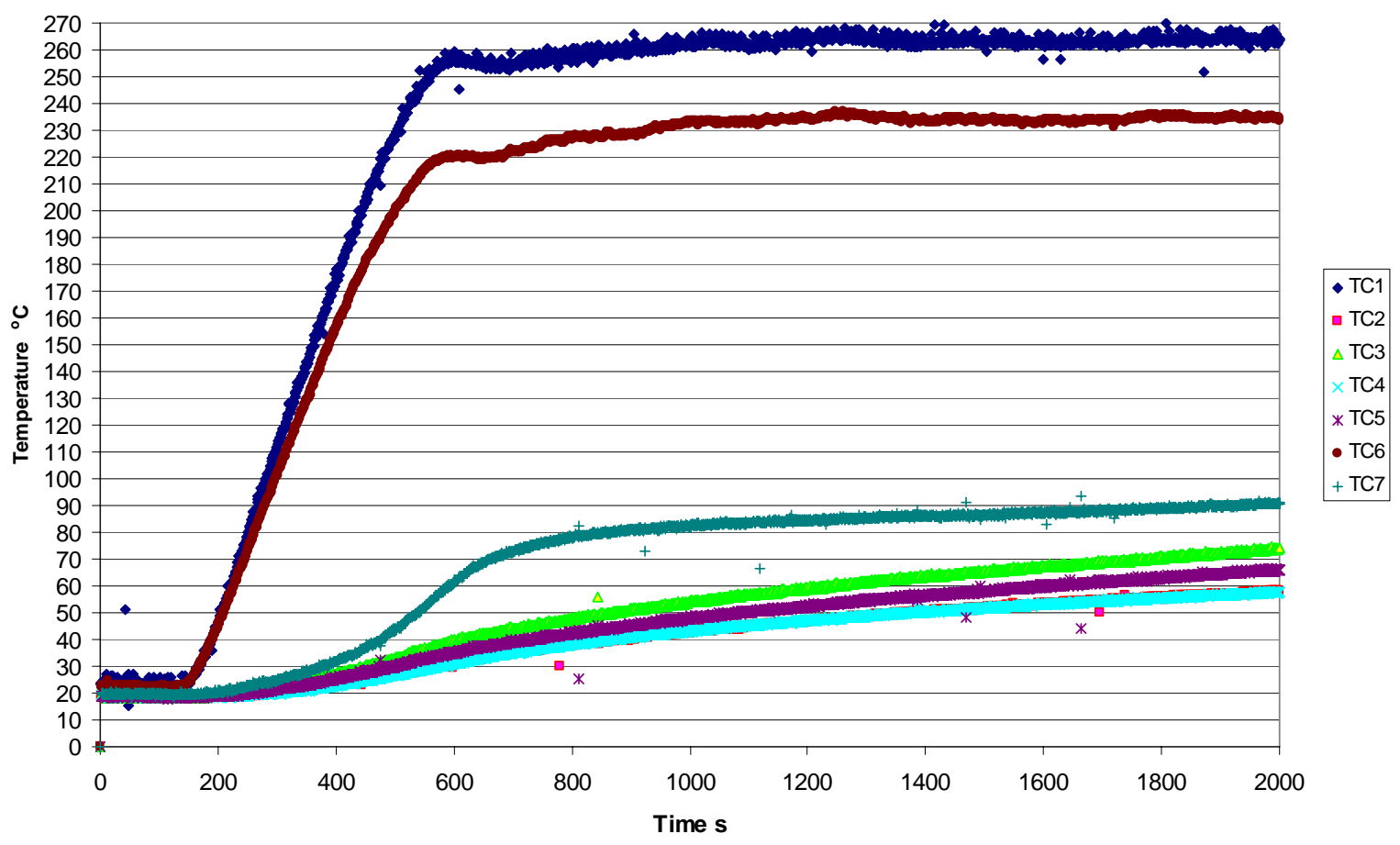

Figure 6 Temperature/time for Ham Hock A 
Ham Hock 3

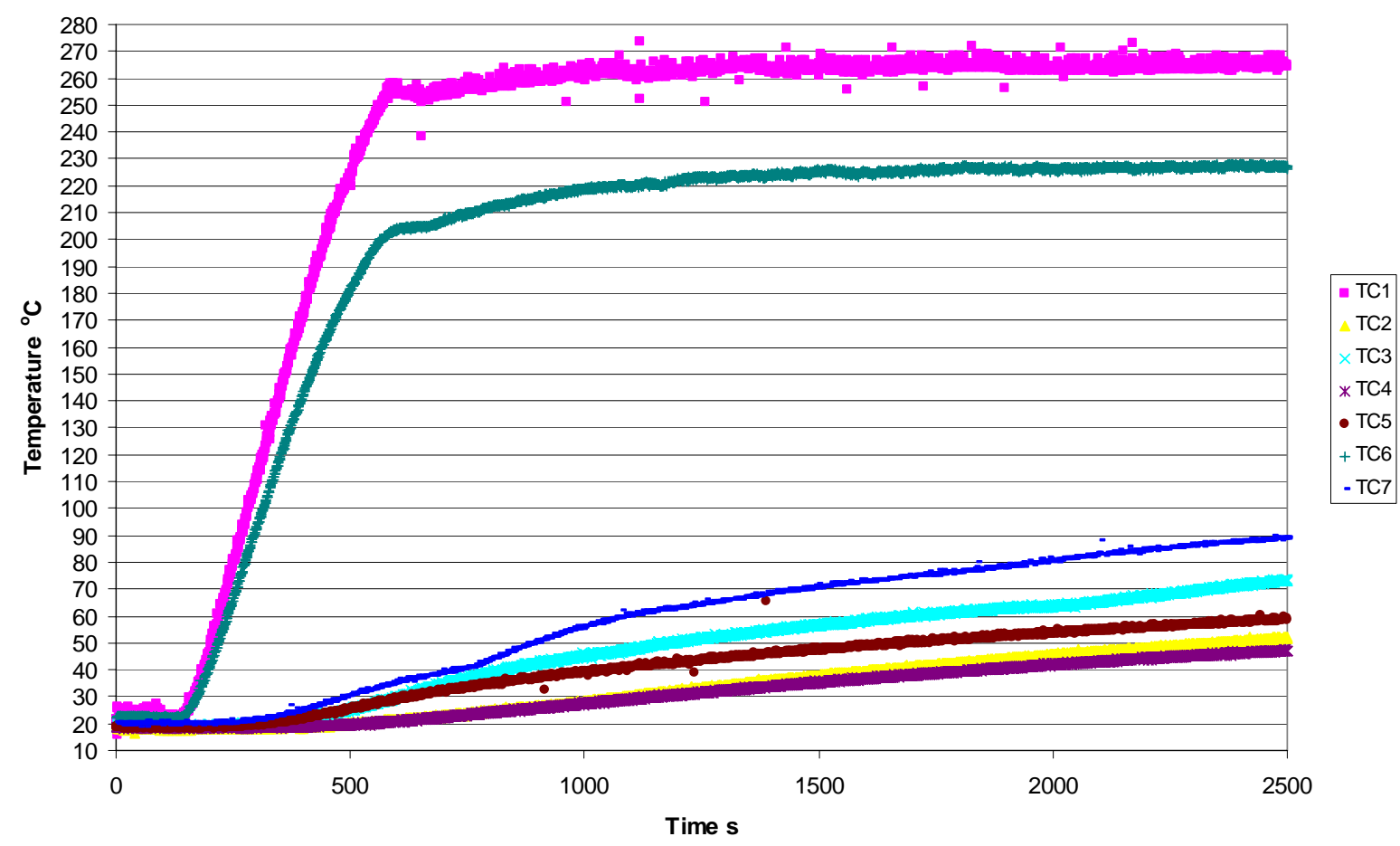

Figure 7 Temperature/time for Ham Hock B

The thermocouple locations were:

- $\mathrm{TC} 1$ - upstream air temperature

- TC2 - under skin right of center

- TC3 - on skin right of center anchored by thread

- TC4 - under skin left of center

- TC5 - on skin left of center anchored by thread

- TC6 - outside sleeve

- $\quad$ TC7 - inside sleeve sewn to fabric

Moritz and Henriques[23] found that when the basal layer of the skin, $80 \mu \mathrm{m}$ below the skin surface, reached $44^{\circ} \mathrm{C}\left(111^{\circ} \mathrm{F}\right)$ the rate of injurious change exceeds that of recovery. The temperature at the surface of the skin will be slightly higher and depends on the intensity of the heat flux [Stoll and Chianta] [24]. For the purposes of this analysis, it will be assumed that when the surface temperature of the simulant reaches $44^{\circ} \mathrm{C}\left(111^{\circ} \mathrm{F}\right)$, damage to the skin will occur. When the skin temperature reaches a value of $57^{\circ} \mathrm{C}\left(135^{\circ} \mathrm{F}\right)$ to $63^{\circ} \mathrm{C}\left(145^{\circ} \mathrm{F}\right)$, third degree burns may occur within one second of exposure [Dussan, B. I., and Weiner, R. I.] [25]. A $60{ }^{\circ} \mathrm{C}$ $\left(140^{\circ} \mathrm{F}\right)$ skin temperature will represent the baseline for determining how long a PASS device needs to operate. For the two ham hocks tested, the minimum time for one of the thermocouples monitoring skin temperature to reach $44^{\circ} \mathrm{C}\left(111^{\circ} \mathrm{F}\right)$ was $8.5 \mathrm{~min}$ and $11.0 \mathrm{~min}$ and to reach 60 ${ }^{\circ} \mathrm{C}\left(140^{\circ} \mathrm{F}\right)$ was $18 \mathrm{~min}$ and $25.7 \mathrm{~min}$ for ham hock $\mathrm{A}$ and $\mathrm{B}$ respectively. It took $11 \mathrm{~min}$ and 12.5 min to reach the operating temperature of $260^{\circ} \mathrm{C}\left(500^{\circ} \mathrm{F}\right)$ for the ham hock $\mathrm{A}$ and $\mathrm{B}$ 
experiments respectively. The $44^{\circ} \mathrm{C}\left(111^{\circ} \mathrm{F}\right)$ times support the Thermal Class III recommendation that the firefighter should only spend 5 min in this zone.

Recommendations for standards for PASS device exposures would include:

- Operation with $95 \mathrm{dBA}$ alarm at a spherical radial distance of $3 \mathrm{~m}(9.9 \mathrm{ft})$ for an operation time of 20 minutes at $260^{\circ} \mathrm{C}\left(500^{\circ} \mathrm{F}\right)$ for Thermal Class III operation.

- Operation with $95 \mathrm{dBA}$ alarm at a spherical radial distance of $3 \mathrm{~m}(9.9 \mathrm{ft})$ for an operation time of 30 minutes at $160^{\circ} \mathrm{C}\left(320^{\circ} \mathrm{F}\right)$ for Thermal Class II operation.

- Battery container strong enough to contain fragments produced by a battery explosion.

The recommended operation time for Thermal Class III is based on the ham hock experiments that suggest an onset of third degree burns as early as 18 min after exposure to elevated temperatures that reach $260^{\circ} \mathrm{C}\left(500^{\circ} \mathrm{F}\right)$. The Thermal Class II recommendation is based on an extrapolation of the ham hock experiments to smaller temperature differences by making the assumption that the energy flux is mostly convective and is proportional to the first power of the temperature difference. The operation times depend on a number of factors, including survival at these temperatures, which currently are not well understood.

Issues for PASS devices that still need resolving include:

- What background sound intensity is encountered on the fire scene and is a $95 \mathrm{dBA}$ at a spherical radial distance of $3 \mathrm{~m}(9.9 \mathrm{ft})$ alarm sufficient to locate a downed firefighter?

- Is the current variation in alarm pitch at the $95 \mathrm{dBA}$ level the best choice for locating a downed firefighter?

- How susceptible is a PASS device to muffling problems?

- How does repeated use of a PASS device affect its operation in critical temperature regions?

- Are operation times for PASS devices sufficient to facilitate rescue at these conditions?

- What number of repeated exposures to Thermal Class I, II, or III conditions can a PASS device withstand and still be regarded as operational?

\section{Future Investigations}

The next phase of this project will focus on defining the thermal classes of operation for emergency radios, and infrared cameras. The impact of repeated exposures of Thermal Class I, II, and III conditions for PASS devices will be documented. The impact of exposure to strong radiant fluxes at elevated temperatures for short time periods will also be investigated. In this last instance, what is being simulated is a situation where a firefighter has spent substantial time in Thermal Class II or III conditions and then is subjected to flashover radiation for a short period of time. This condition would occur when a firefighter is involved with a rescue, or a retreat from a Thermal Class IV condition. Experiments are also being planned to better define the required operational times for Thermal Class I, II, and III. 


\section{Acknowledgement}

This work was sponsored the Department of Homeland Security (DHS) via the NIST Office of Law Enforcement Standards (OLES) to advance the development of Standards for Electronic Equipment used by Emergency Responders. 


\section{References}

1. National Fire Protection Association, NFPA 1971 Standard on Protective Ensemble for Structural Fire Fighting, 2000 Edition, Volume 11. National Fire Protection Association, 1 Batterymarch Park, P.O. Box 9101, Quincy, MA 02269-9101.

2. National Fire Protection Association, NFPA 1500 Standard on Fire Department Occupational Safety and Health Program, 2002 Edition, Volume 10. National Fire Protection Association, 1 Batterymarch Park, P.O. Box 9101, Quincy, MA 02269-9101.

3. National Fire Protection Association, NFPA 1982 Standard on Personal Alert Safety Systems (PASS), 1998 Edition, Volume 12. National Fire Protection Association, 1 Batterymarch Park, P.O. Box 9101, Quincy, MA 02269-9101.

4. Bryner, N. P., Madrzykowski, D., Stroup, D. W., "Performance of Thermal Sensors in Personal Alert Safety System (PASS) Devices" National Institute of Standards and Technology, Gaithersburg, Internal report in review.

5. National Fire Protection Association, NFPA 1221 Standard on Personal Alert Safety Systems (PASS), 1998 Edition, Volume 12. National Fire Protection Association, 1 Batterymarch Park, P.O. Box 9101, Quincy, MA 02269-9101.

6. National Fire Protection Association, NFPA 1981 Standard on Open-Circuit Self-Contained Breathing Apparatus for the Fire Service, 2002 Edition, Volume 12. National Fire Protection Association, 1 Batterymarch Park, P.O. Box 9101, Quincy, MA 02269-9101.

7. MIL-STD-810F, Department of Defense, United States of America, 2000.

8. Underwriters Laboratories, Inc., 333 Pfingsten Road, Northbrook, IL 60062.

9. Ordinanz, W., "Work in Hot Environments and Protection against Heat", The Iron and Steel Institute, London. 1970.

10. Abbott, N. J. and Schulman, S., "Protection from Fire: Nonflammable Fabrics and Coatings," Proceedings of 1976 International Symposium on Flammability and Fire Retardants. Ontario, Canada, May 6-7, 1976.

11. Colletta, G. C., Arons, I. J., Ashley, L. E., and Drennan, A. P., "The Development of Criteria for Firefighters' Gloves Volume I: Glove Requirements. U. S. Department of Health, Education, and Welfare, Public Health Service, Center for Disease Control, National Institute for Occupational Safety and Health, Division of Physical Sciences and Engineering, Cincinnati, Ohio February, 1976.

12. Abeles, Fred J., "Protective Ensemble Performance Standards, Project Fires" Phase 1B Final Report, Volume 2, Grumman Aerospace Corporation, Bethpage, New York, May 1980.

13. Duffy, R. M., Sawicki, J. C., Beer, A. R., "Project Fires: Firefighters Integrated Response Equipment System - The Final Report," International Association of Firefighters, Department of Occupational Health and Safety, Washington D.C., 1985.

14. Federal Emergency Management Agency/United States Fire Administration "Minimum Standards on Structural Fire Fighting Protective Clothing and Equipment: A Guide for Fire Service Education and Procurement," FA-137, United States Fire Administration, 16825 South Seton Avenue, Emmitsburg, MD 21727. December 1992.

15. Foster, J. A. and Roberts, G.V., "Measurements of the Firefighting Environment - Summary Report," Central Fire Brigades Advisory Council Research Report number 61, 1994, Home Office Fire Research and Development Group, Fire Engineers Journal, United Kingdom, September 1995. 
16. Lawson, J. R., "Thermal Performance and Limitations of Bunker Gear," Fire Engineering, Vol. 151 No. 8, Penn Well Publishing Company, Saddle Brook, NJ, August 1998.

17. Babrauskas, V.; Peacock, R. D.; Reneke, P. A., "Defining Flashover for Fire Hazard Calculations. Part 2.," Fire Safety Journal, Vol. 38, No. 7, 613-622, November 2003.

18. Lawson, J. R., "Firefighter's Protective Clothing and Thermal Environments of Structural Fire Fighting," National Institute of Standards and Technology, Gaithersburg, MD, U.S. Fire Administration, Emmitsburg, MD, NISTIR 5804; August 1996.

19. Quintiere, J., "The Spread of Fire From a Compartment - A Review," National Bureau of Standards (currently NIST), prepared for an American Society for Testing and Materials, ASTM Symposium, June 1978.

20. Gross, D. and Fang, J. B., "The Definition of a Low Intensity Fire," National Bureau of Standards (currently NIST), Special Publication 361, Volume 1: Performance Concept in Buildings; Proceedings of the Joint RILEM-ASTM-CIB Symposium, May 1972, 1972.

21. Lawson, J. R.1, and Twilley, W. H., "Development of an Apparatus for Measuring the Thermal Performance of Firefighters' Protective Clothing," National Institute of Standards and Technology, Gaithersburg, MD, NISTIR 6400; October 1999.

22. Purser, David A, "Toxicity Assessment of Combustion Products," The SFPE Handbook of Fire Protection Engineering Third Edition, National Fire Protection Association, One Batterymarch Park, Quincy, Ma. 02269-9101 (2002)

23. Moritz, M. D. and Henriques, F. C., "Studies of Thermal Injury II. The Relative Importance of time and Surface Temperature in the Causation of Cutaneous Burns" American Journal of Pathology, 23: 695-720 (1947)

24. Stoll, A. M. and Chianta, M. A., "Heat Transfer Through Fabrics as Related to Thermal Injury," Transactions of the New York Academy of Sciences, 33, 648-670: (1971)

25. Dussan, B. I. and Weiner, R. I., "Study of Burn Hazard in Human Tissue and Its Implication on Consumer Product Design," The American Society of Mechanical Engineers Winter Meeting, Washington, D. C., November (1971).

26. McCaffrey, B. J., and Heskestad, G., "A Robust Bidirectional Low-velocity Probe for Flame and Fire Application", Combustion and Flame, 26:125-127 (1976). 


\section{Appendix A}

\section{Fire Equipment Evaluator Instrumentation Specifications}

A $25 \mathrm{~kW}$ air duct heater (Omega Model No. ADH-025/480V/3P) ${ }^{*}$ is positioned in the vertical section of the tunnel to provide heat to the air flow. The heater is comprised of a bank of tubular elements through which the airflow must pass. The elements are sheathed in Incoloy, a nickeliron-chromium alloy, for protection against corrosion and oxidation. The heater is housed in a $38 \mathrm{~cm}$ (15 in) by $61 \mathrm{~cm}$ ( $24 \mathrm{in}$ ) cross sectional area that was sized to the heater. The expansion area of the airflow approaching the heater expands at an approximately 30 degree angle, the maximum expansion angle allowable for the heater. A diagram and pictures of the FEE are presented in Figure A1, A11, and A12.

Aluminum honeycomb, $10.2 \mathrm{~cm}$ (4.0 in) thick with a $0.3175 \mathrm{~cm}(1 / 8 \mathrm{in})$ cell size is positioned at the entrance to the heater expansion area and $5.1 \mathrm{~cm}(2.0 \mathrm{in})$ thick, $0.95 \mathrm{~cm}(3 / 8 \mathrm{in})$ cell stainless steel honeycomb is positioned $61.3 \mathrm{~cm}$ (24 1/8 in) from the center of the door in the measurement chamber. The purpose of the honeycomb is to create a uniform flow in the measurement chamber.

The heater is controlled by a SCR controller (Omega Model No. SCR 73P-480-060-59) connected to a ramp and soak temperature controller (Omega Model No. CN8201-F1).

A thermocouple placed in the airflow directly beyond the heater provides feedback to the temperature controller. The temperature controller sends a signal to the SCR, which controls the heater until the desired air temperature is reached.

Temperature measurements were made using type $\mathrm{K}$ thermocouples. Bare-bead thermocouples were used to measure downstream airflows. A thermocouple equipped with a radiation shield was used to measure the temperature near the heater.

Measurements of the air flow velocity in the tunnel use a bidirectional probe connected to a differential pressure transducer (Setra, Model 264), with an accompanying thermocouple. Bidirectional probes have the advantages of being robust, adjustable to changing temperatures, and fairly insensitive to the mounting angle. The bidirectional probe measures the velocity, $v$, as a function of the pressure drop, $\Delta p$, across the probe, and the fluid temperature, $T$, at the probe location according to the equation:

$$
v=\frac{1}{K} \sqrt{\frac{(2 \Delta p)}{\rho}}, \text { where } \rho=\frac{(M W) P_{\text {absolute }}}{R T} .
$$

The density, $\rho$, is computed as a function of temperature using the ideal gas law. The air is assumed to be pure, with a molecular weight $(M W)$ of $0.029 \mathrm{~kg} / \mathrm{mol}$. Here $P_{\text {absolute }}$ is the absolute barometric pressure and $R$ is the universal gas constant $8.314 \mathrm{~J} / \mathrm{mol} \mathrm{K}$. The $K$ is a constant, 1.08 , as reported by McCaffrey and Heskestad [26].

\footnotetext{
* The identification of any commercial product or trade name does not imply endorsement or recommendation by the National Institute of Standards and Technology.
} 
To measure the pressure differential, the bidirectional probe is connected to a very low differential pressure transducer (Setra, Model 264). The transducer has bidirectional operation over the range of $\pm 12 \mathrm{~Pa}\left(0.05\right.$ in $\left.\mathrm{H}_{2} \mathrm{O}\right)$, with an accuracy of $\pm 1 \%$ of full scale.

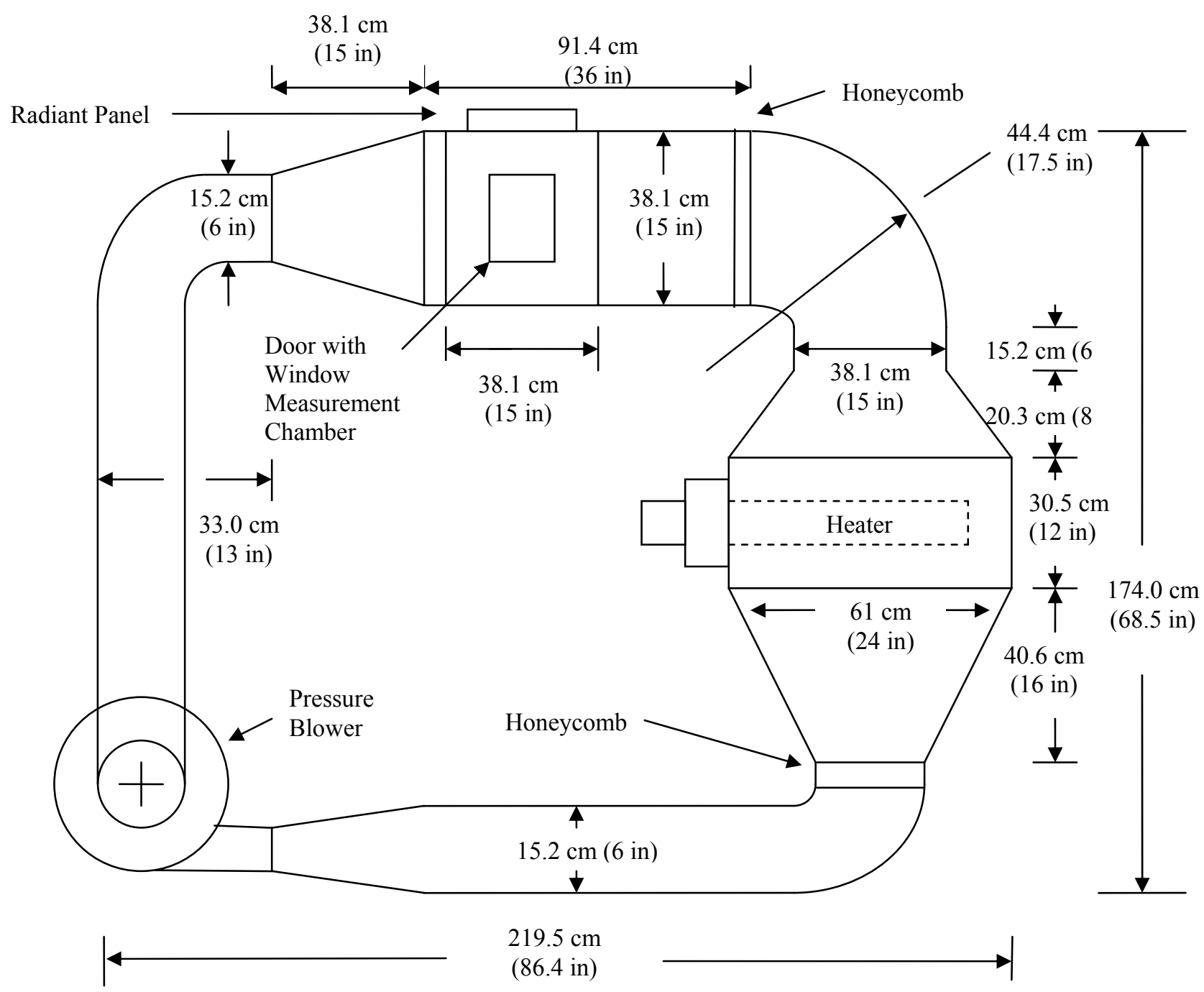

\section{Figure A1 Drawing of FEE tunnel}

Two water-cooled Medtherm Schmidt Boelter total heat flux gages, model number 64-2-18, are used to measure the heat flux. The gages were calibrated over the range of $0 \mathrm{~kW} / \mathrm{m}^{2}$ to $15 \mathrm{~kW} / \mathrm{m}^{2}$. 
Radiant heating is supplied using an electric infrared heater (radiant panel) composed of metal heating elements secured to a ceramic face. The heater is a Thermaking model, manufactured by Thermal-tech Corporation and has a short heat up time of $10 \mathrm{~s}$. The surface area of the heater is $25 \mathrm{~cm}$ by $35 \mathrm{~cm}$ and is capable of a maximum flux of $23.25 \mathrm{~kW} / \mathrm{m}^{2}$. A digital SCR controller is used to regulate the heater operation. A built-in thermocouple monitors the element temperature, providing feedback to the SCR in order to control the heater.

The airflow is supplied by a high temperature pressure blower (Cincinnati Fan Model PBS-12A) with a maximum air supply of $293 \mathrm{~L} / \mathrm{s}(620 \mathrm{cfm})$. The blower is powered by an externally mounted $3 / 4$ horsepower motor (Baldor custom inverter duty motor).

Data from the measurement instruments is collected at a rate of $1 \mathrm{~Hz}$. This rate is sufficient to characterize the changes in the thermal environment experienced by the test equipment.

The temperature profile across the top of the tunnel at the door is given in Figures A2 - A10 for three different flow velocities. The higher flow speeds produce a more uniform temperature distribution across the tunnel. A thermocouple tree, oriented vertically in the tunnel and located on the door centerline, was used to measure the temperature The thermocouples were spaced at $3.8 \mathrm{~cm}, 7.6 \mathrm{~cm}, 11.4 \mathrm{~cm}, 19.0 \mathrm{~cm}$, and $22.9 \mathrm{~cm}(1.5 \mathrm{in}, 3 \mathrm{in}, 4.5 \mathrm{in}, 7.5 \mathrm{in}$, and 9 in) \{TC1, TC3, TC4, TC5 and TC6 3 from the ceiling. The tree was located at one of three positions: near the back wall $7.6 \mathrm{~cm}(3 \mathrm{in})$ from the back wall, centered $19.0 \mathrm{~cm}$ (7.5 in) from back wall, and near the door $7.6 \mathrm{~cm}$ ( $3 \mathrm{in}$ ) from the door. Thermocouple TC1 was fixed centered in the tunnel and upstream $10.2 \mathrm{~cm}$ (4 in) from the door centerline. The bidirectional probe was located in this position to monitor the flow velocity. 


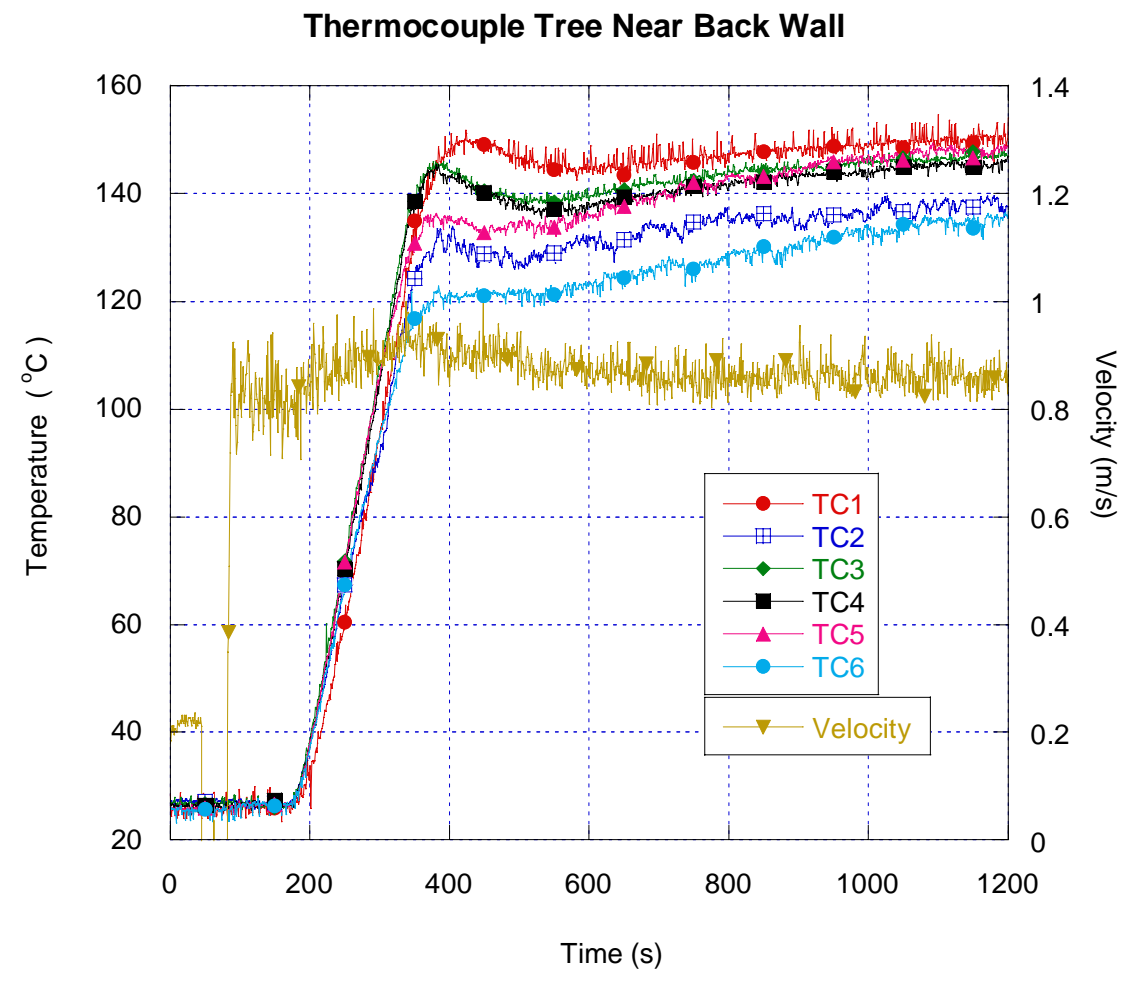

Figure A2 Temperature Profiles near the Back Wall at a Nominal Velocity $0.9 \mathrm{~m} / \mathrm{s}$

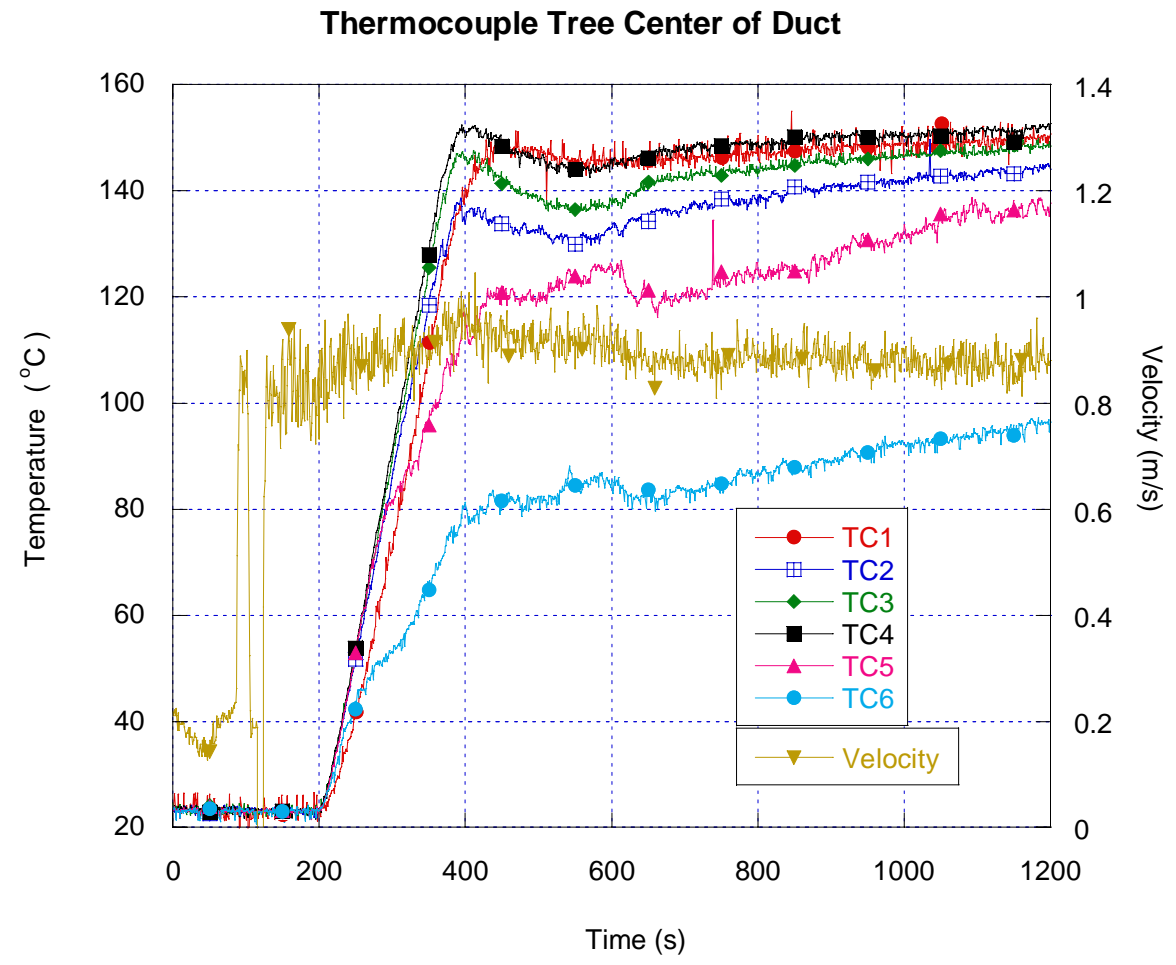

Figure A3 Temperature Profiles at the Center of the Duct at a Nominal Velocity $0.9 \mathrm{~m} / \mathrm{s}$ 


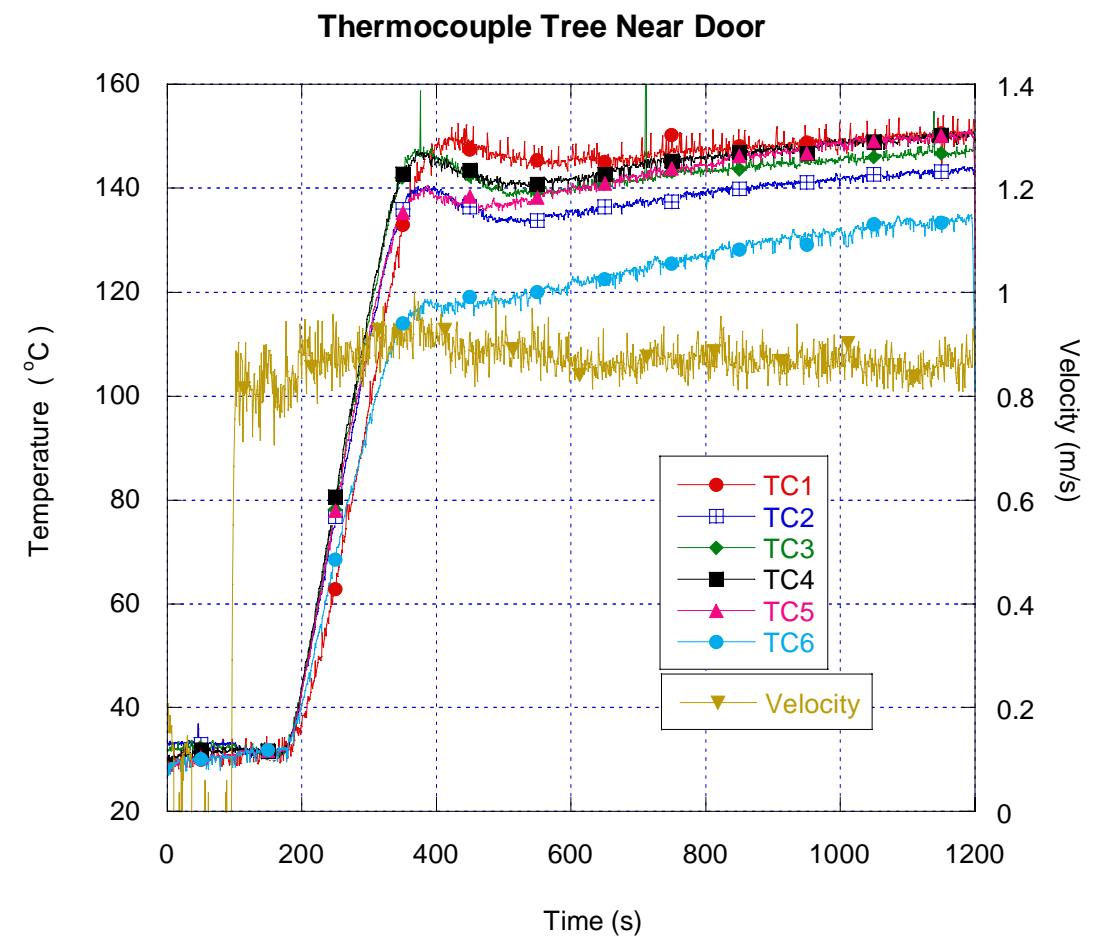

Figure A4 Temperature Profiles near the Door at a Nominal Velocity $0.9 \mathrm{~m} / \mathrm{s}$

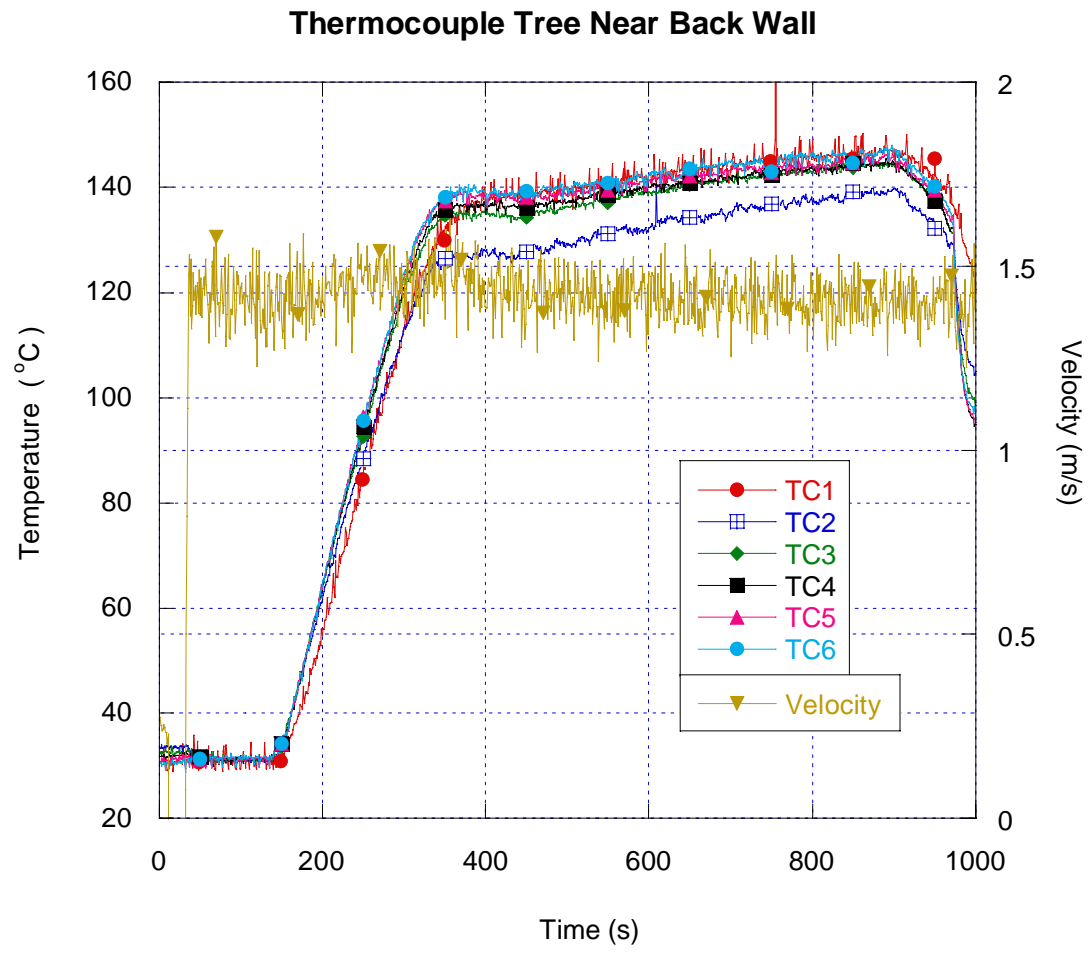

Figure A5 Temperature Profiles near the Back Wall at a Nominal Velocity $1.4 \mathrm{~m} / \mathrm{s}$ 


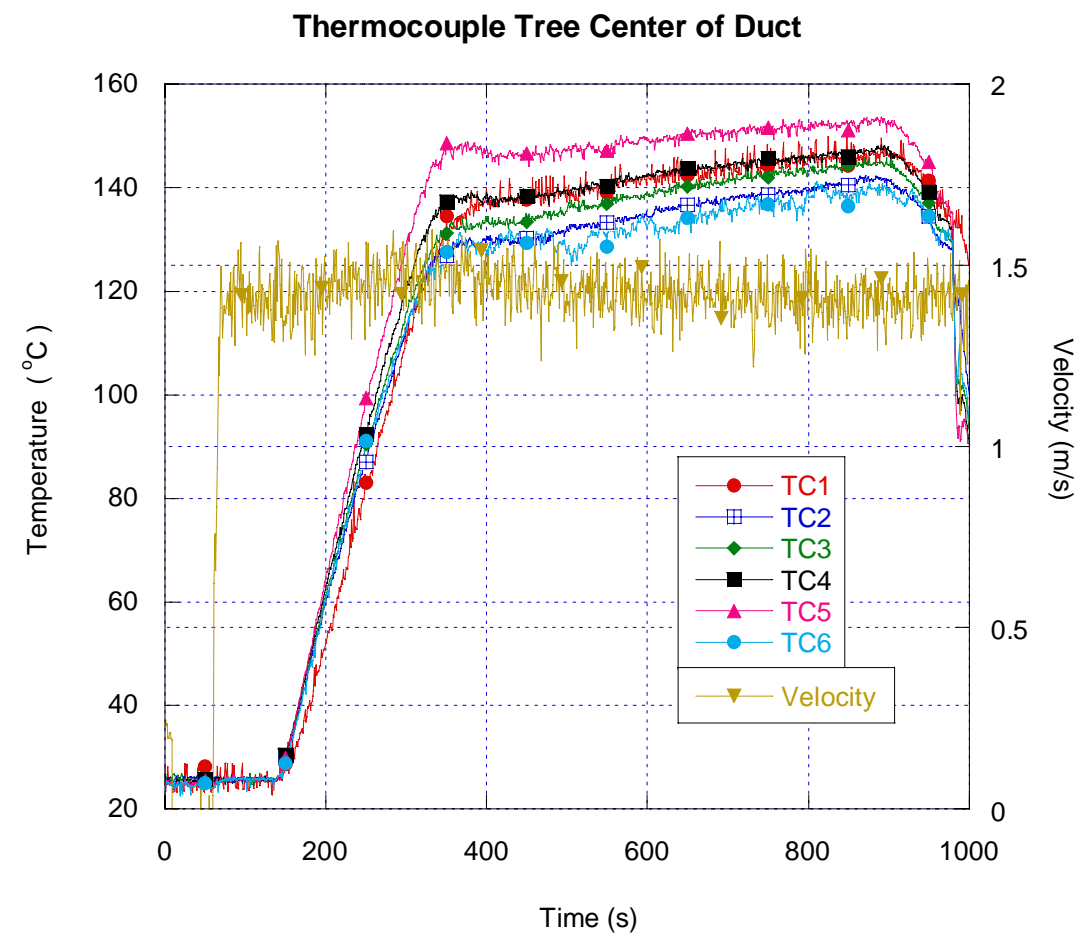

Figure A6 Temperature Profiles near the Center of the Duct at a Nominal Velocity $1.4 \mathrm{~m} / \mathrm{s}$

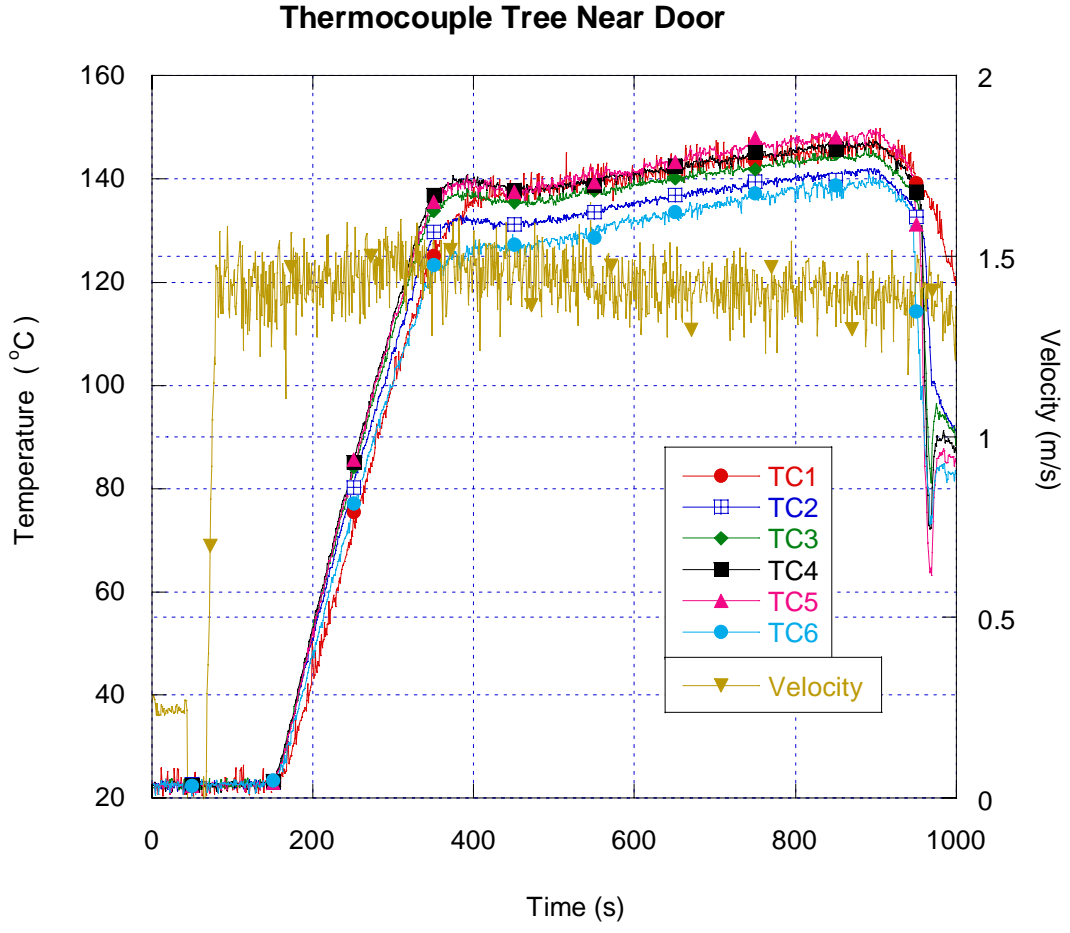

Figure A7 Temperature Profiles near the Door at a Nominal Velocity $1.4 \mathrm{~m} / \mathrm{s}$ 


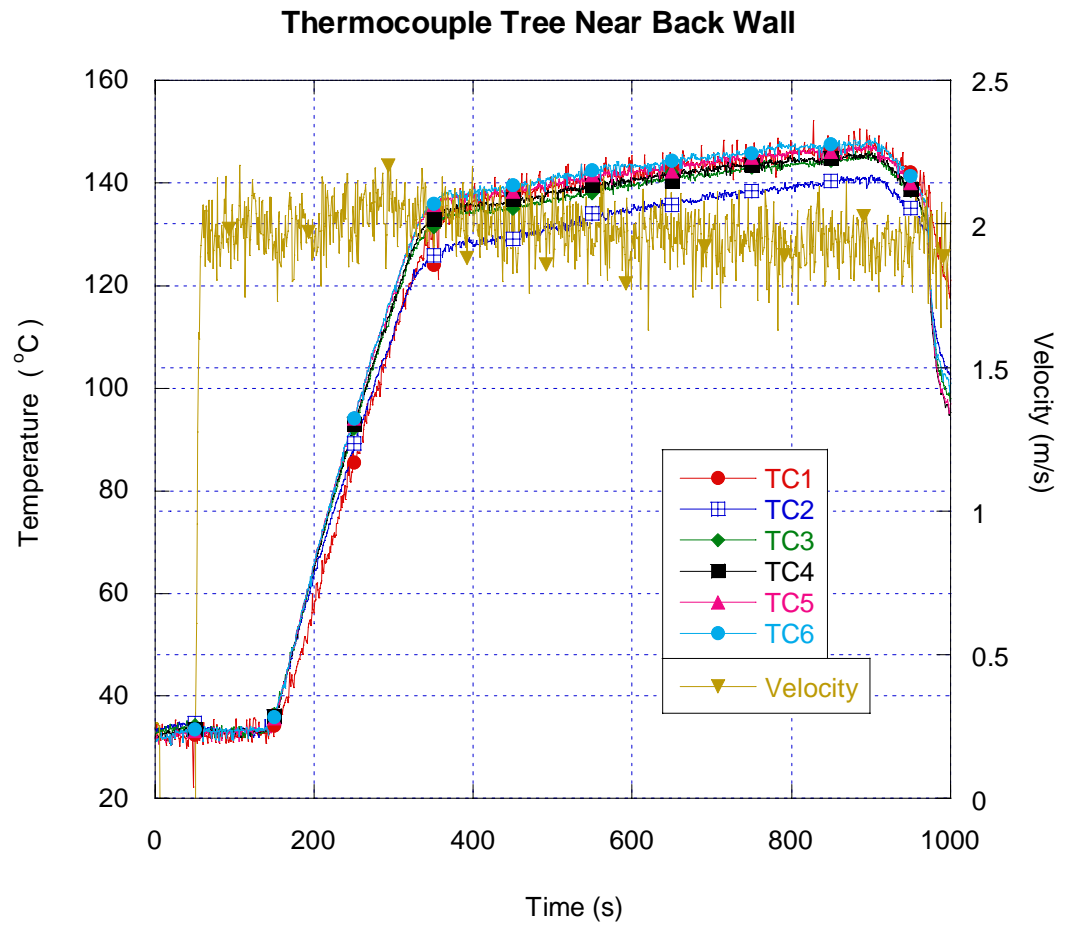

Figure A8 Temperature Profiles near the Back Wall at a Nominal Velocity $1.9 \mathrm{~m} / \mathrm{s}$

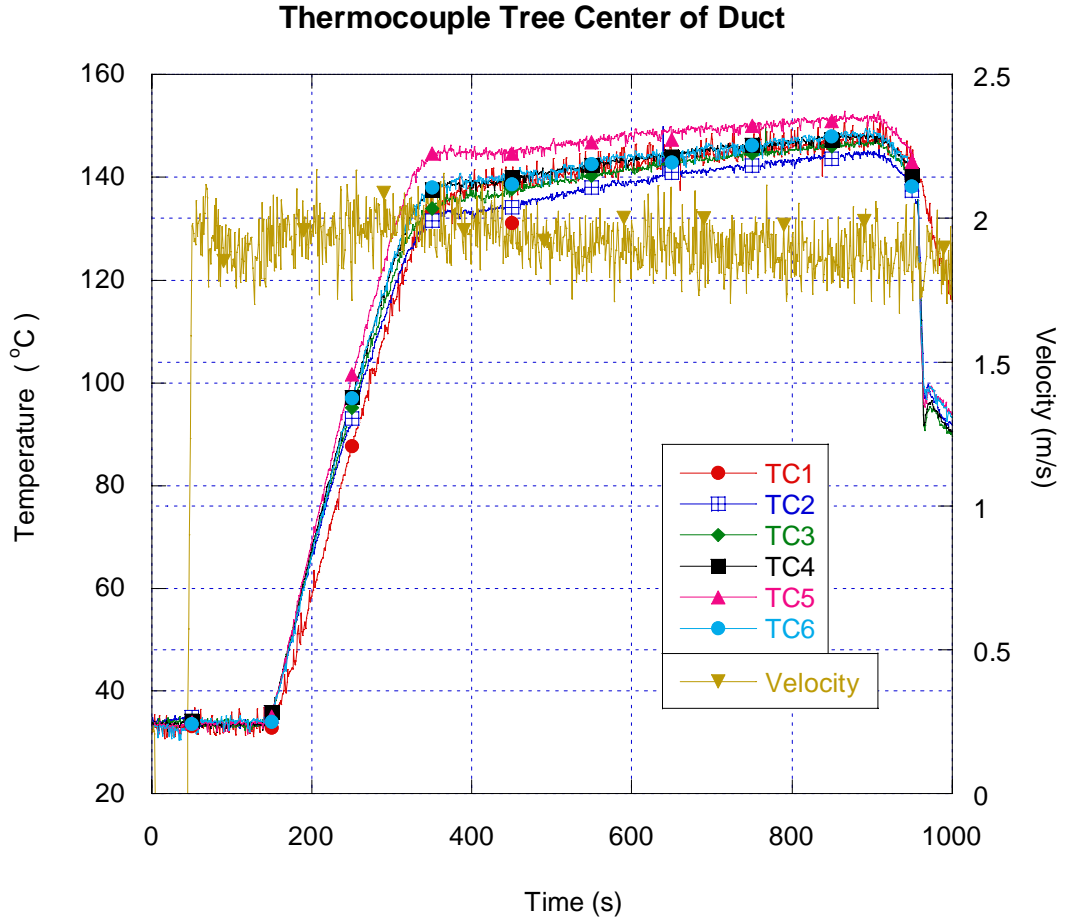

Figure A9 Temperature Profiles near the Center of the Duct at a Nominal Velocity $1.9 \mathrm{~m} / \mathrm{s}$ 


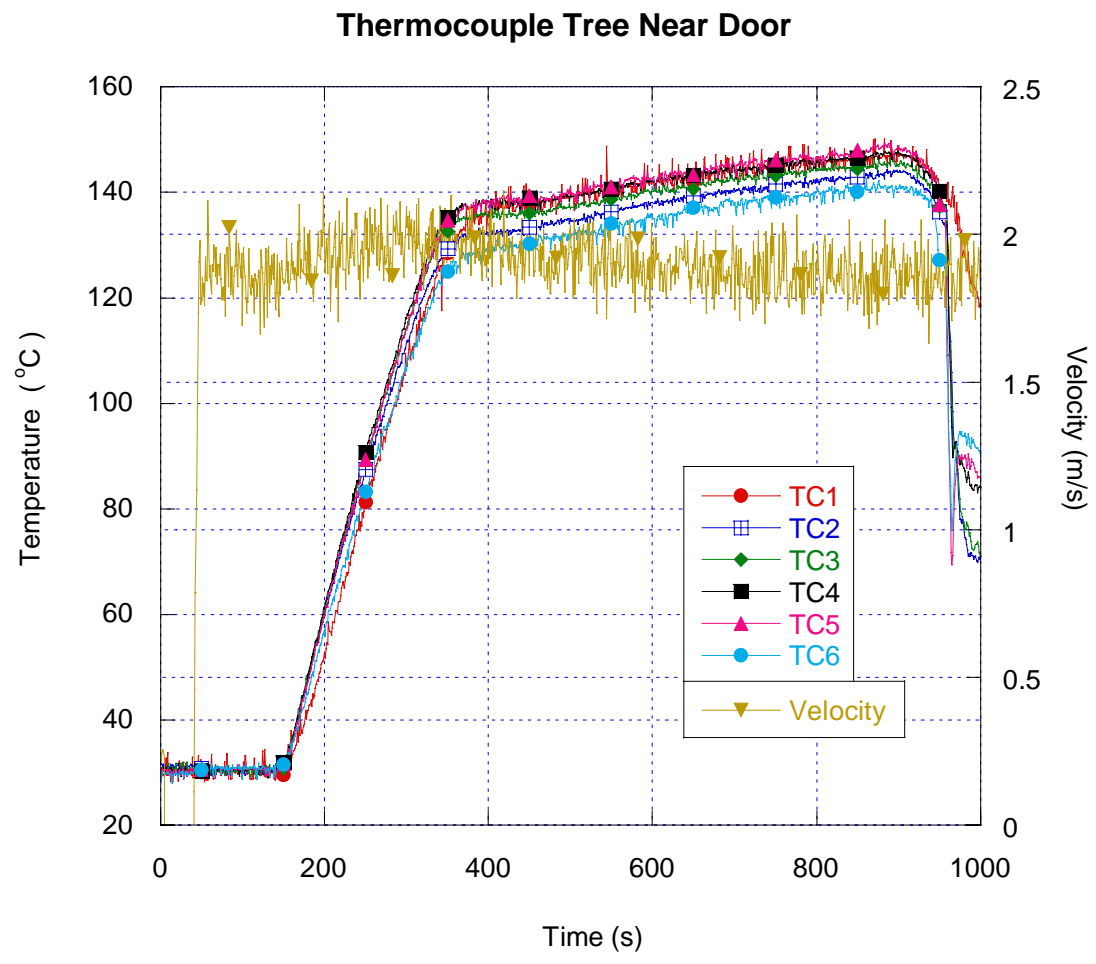

Figure A10 Temperature Profiles near the near the Door at a Nominal Velocity $1.9 \mathrm{~m} / \mathrm{s}$ 


\section{Photographs of the FEE}

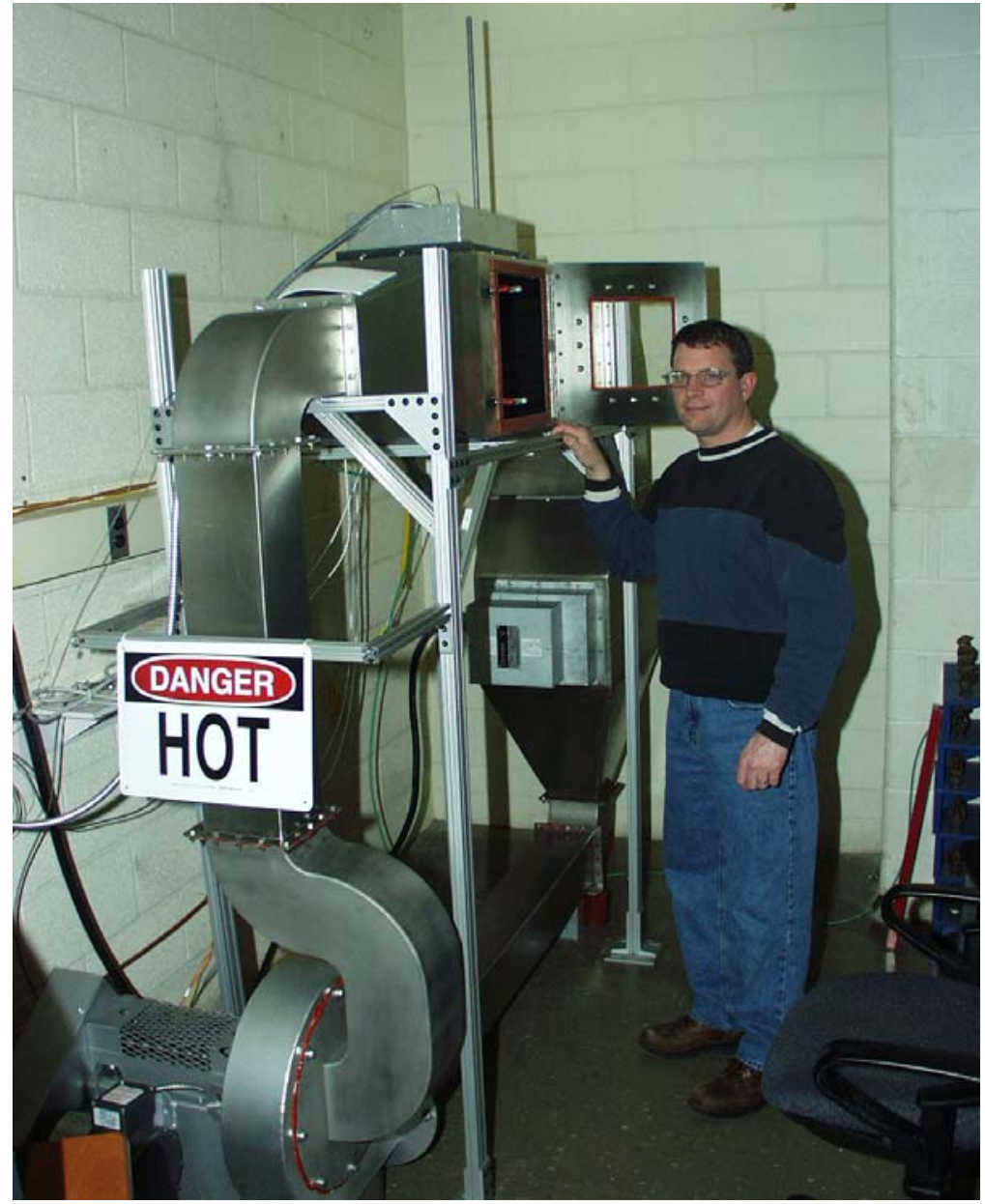

Figure A11 Photograph of FEE tunnel and operator Michael Selepak.

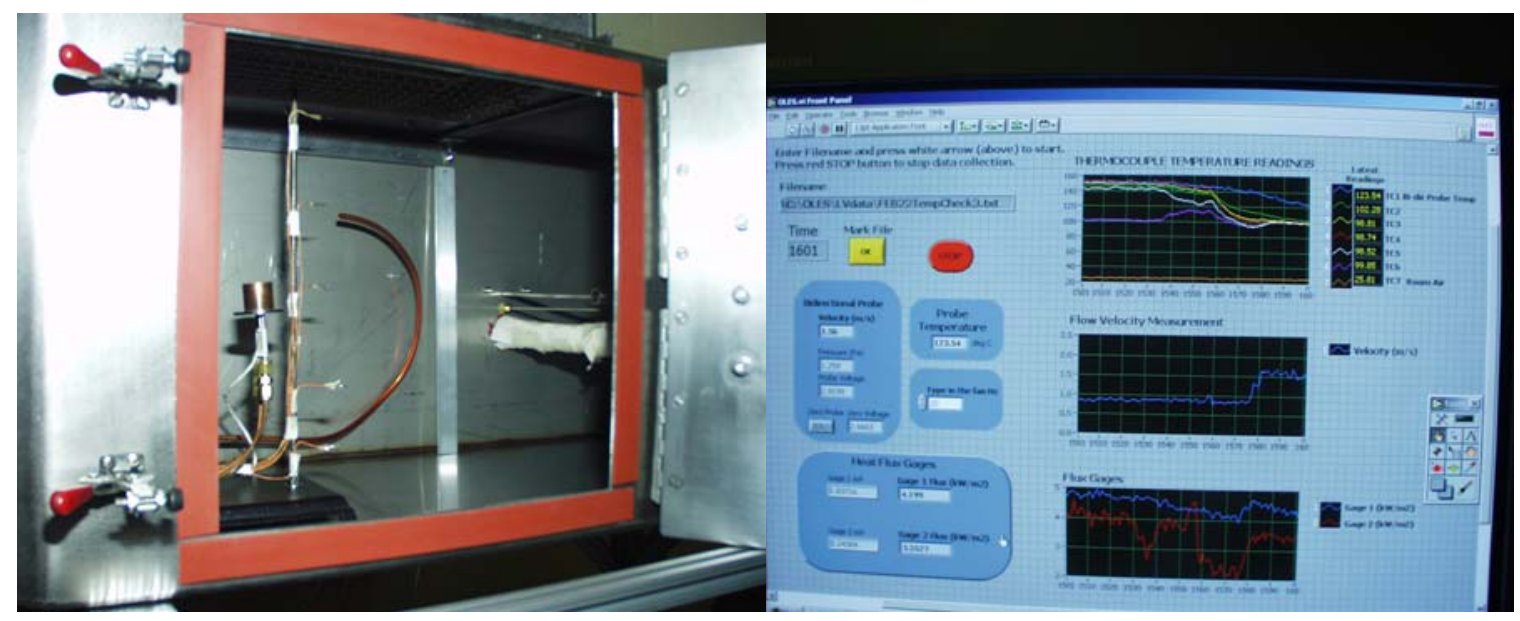

Figure A12 Photograph of FEE test section and data program 
